\author{
The Ptolemaic Oinochoai: A Reassessment \\ Elizabeth A. Waraksa
}

\title{
Introduction
}

The corpus of Ptolemaic oinochoai or so-called "Queens' Vases" consists of more than 300 fragments and a few nearly complete examples ${ }^{1}$ of faience jars which, in their finished state, were typically decorated with a high-relief image of a Ptolemaic queen standing and turning towards her right while extending a phiale (offering bowl) towards an altar, with a pointed, garlanded pillar on her left. ${ }^{2}$ [Figure 1] In their material, decoration and iconography, the Ptolemaic oinochoai form a homogeneous group of fine ware produced during a limited chronological horizon, namely the better part of the $3^{\text {rd }}$ century BCE. ${ }^{3}$ The vessels' creative

${ }^{1}$ See the catalogue of Dorothy Burr Thompson, The Ptolemaic Oinochoai and Portraits in Faience (Oxford: Clarendon Press, 1973), to which add the additional fragments published in R.A. Lunsingh Scheurleer, "Faïence ptolémaïque. Remarques sur quelques inédits." Bulletin van de Vereeniging tot Bevordering der Kennis van de Antieke Beschaving te 's-Gravenhage 49 (1974) 265-267; Klaus Parlasca, “Zur Verbreitung ptolemäischer Fayencekeramik ausserhalb Âgyptens,” Jahrbuch des Deutschen Archäologischen Instituts 91 (1976) 135-156; D.B. Thompson, “More Ptolemaic Queens.” Eikones: Studien zum griechischen und romischen Bildnis: Hans Zucker zum sechzigsten Geburstag gewidmet (Bern: Francke, 1980) 181-184; Simone Besques, "Un nouveau fragment d’oenochoé ptolémaïque en faïence.” Alessandria e il Mondo Ellenistico-Romano: Studi in Onore di Achille Adriani. Studi e materiali 5. (Rome: L'Erma di Bretschneider, 1984) II: 273-276; Irmgard Kriseleit, "Fragmente von Ptolemäerkannen in der Antikensammlung.” Forschungen und Berichte 28 (1990) 61-64; Hans Georg Niemeyer, “Eine Ptolemäerkanne aus Karthago.” Hommages à Jean Leclant. Bibliothèque d’Étude 106. (Cairo: Institut Français d'Archéologue Orientale, 1993) III: 391-395; Hans Georg Niemeyer and Roald F. Doctor, "Karthago: Hamburger Grabung unter dem Decumanus Maximun.” Mitteilungen des Deutschen Archaeologischen Instituts, Roemische Abteilung 100 (1993) 201-244; Jean-Yves Empereur, “Travaux menés en collaboration avec l'École française en 1996: Alexandrie (Égypte).” Bulletin de correspondence héllenique 121 (2) (1997) 831-847; Marie-Dominique Nenna and Merwatte Seif ElDin, La vaiselle en faïence d'époque gréco-romaine. Études alexandrines 4. (Cairo: Institut Français d'Archéologue Orientale, 2000) 396-399 and pl. 76; Sally-Ann Ashton, "Faience and the Ptolemaic Royal Cult: Further fragments and thoughts.” Faraoni come Dei. Tolemei come Faraoni. Atti del V Congresso Internazionale Italo-Egiziano. Torino 8-12 Deciembre 2001. Eds Nicola Bonacasa et al. (Turin: Museo Egizio, 2003) 334-339; the nearly complete vessel, J. Paul Getty Museum 96.AI.58 (ex-collection Barbara and Lawrence Fleischman), for which see Arielle P. Kozloff, "Is There an Alexandrian Style - What Is Egyptian about It?” Alexandria and Alexandrianism (Malibu, CA: J. Paul Getty Museum, 1996) 253, fig. 4, ibid., “Queen’s Vase” [cat. no. 62], Gifts of the Nile: Ancient Egyptian Faience. Ed. Florence Dunn Friedman. (New York: Thames \& Hudson, 1998), 99, 200, and “Oinochoe Depicting Berenike II.” The J. Paul Getty Museum Handbook of the Antiquities Collection. Second edition. Eds. Kenneth Lapatin and Karol B. Wight. (Los Angeles: J. Paul Getty Museum 2010) 99; and the nearly complete vessel Museumslandschaft Hessen Kassel Antikensammlung T 1018, published in Türkis und Azur: Quarzkeramik im Orient und Okzident. Eds. Ralf Busz und Peter Gercke, (Wolfratshausen: Edition Minerva, 1999) 368-370, cat. no. 212. It is likely that yet more fragments remain unrecognized or unpublished in repositories worldwide.

2 One rare faience oinochoe fragment in the British Museum (2001,0429.1; see Ashton 2003 and http://www.britishmuseum.org/research/collection online/collection_object details/collection_image gallery.aspx?

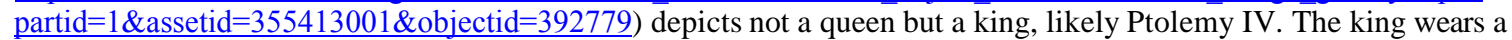
diadem and a cloak hangs over his left shoulder. The hair framing the king's face - that is, the portion not held back by the diadem - is distinguished with a brown-colored glaze. Like the typical scene featuring a queen, the king's head is turned towards the right and his upper right arm extends away from his body, as though he is standing and pouring a libation. It has, however, been suggested by Ashton (2003) that the king may be seated.

${ }^{3}$ Using epigraphy and stylistic analysis, D.B. Thompson dates the vessels from the reign of Arsinoe II (275 BCE) to the end of the reign of Cleopatra I (176 BCE): Ptolemaic Oinochoai, 21-22, 46-48, 78-101. Recently, Ashton has proposed narrowing 
blending of a characteristically Egyptian material, faience, with Greek and Persian ${ }^{4}$ iconographic elements, as well as Greek inscriptions evoking the cult of the deified Ptolemies and linking Ptolemaic queens with divine manifestations such as Isis and Agathe Tyche, distinguishes them from other contemporary ceramics. The careful use of polychrome and gilding on the vessels further suggests that the oinochoai were luxury items conceived within and circulating among the Ptolemaic royal court. This aspect of the vessels, namely, their material elaboration, is deserving of renewed attention. When considered together with the vessels' geographic distribution and the cultural makeup of the Alexandrian priestly class in the $3^{\text {rd }}$ century BCE, a more nuanced picture of the vessels' ancient functions and potential ownership emerges.

The vast majority of faience oinochoai fragments derive from Alexandria, with many having been excavated from the Chatby, Hadra and Kom el-Shugafa cemeteries in the early part of the $20^{\text {th }}$ century; ${ }^{5}$ more recently, several fragments have been uncovered in habitation zones. ${ }^{6}$ A number of fragments derive from elsewhere in Lower Egypt (i.e. Bubastis, Canopus, Naukratis, and Memphis) and some of these may have been produced locally, though this remains speculative. While there may have been workshops outside of Alexandria that were capable of manufacturing such oinochoai - a question to which we shall briefly return later - it is probable that the better part of the corpus was produced in Alexandria by artisans working under royal supervision. Unfortunately, no faience workshops of Ptolemaic date have (yet) been uncovered at Alexandria. ${ }^{7}$

the period during which the vessels were produced, suggesting a cessation during the reign of Ptolemy IV (205 BCE) (2003: 334-339).

${ }^{4}$ The primary Persian element seen on the oinochoai is the royal fillet: D.B. Thompson, Ptolemaic Oincohoai, 28 and n.3; Türkis und Azur, 368. For a detailed study of the acheminizing features of early Ptolemaic art, see Michael Pfrommer, "Roots and Contacts: Aspects of Alexandrian Craftsmanship.” In Alexandria and Alexandrianism (Malibu: The J. Paul Getty Museum, 1996) 171-189.

${ }^{5}$ D.B. Thompson, The Ptolemaic Oinochoai, 8-9 and Catalogue (125-198); Nenna and Seif El-Din, La vaiselle en faïence, 396399.

${ }^{6}$ Empereur, “Alexandrie (Égypte),” 841-842 and fig. 13. See also Marie-Dominique Nenna, “Vaiselle en faïence, en métal, en verre et en cérmaique: Filiations et imitations dans l'Égypte ptolémaïque.” Cérmaiques hellénistiques et romaines: productions et diffusion en Méditerranée orientale (Chypre, Égypte et côte syro-palestinienne). Eds. Francine Blondé, Pascale Ballet and Jean-François Salles. Travaux de la Maison de l’Orient méditerranéen 35 (Lyon: Maison de l'Orient et de la Méditerranée Jean Pouilloux 2002) 323.

${ }^{7}$ Marie-Dominique Nenna and Mervat Seif El-Din, “La vaiselle en faïence du musée gréco-romain d'Alexandrie.” Bulletin du correspondence hellénique 117 (2) (1992) 565-602. 
In addition to the fragmentary faience oinochoai found in Egypt, a significant number of oinochoai - indeed, some of our most complete examples - derive from locales outside of Egypt and around the Mediterranean basin, including Athens, Crete, Cyprus, and Xanthos [Figure 2]. This broad distribution must be examined more closely, for it is exactly this diffusion that allows us to reconstruct the vessels' functions and ownership.

In reconsidering the vessels' multimedia nature, royal iconography, inscriptions, and pan-Mediterranean findspots, it will be asserted here that the so-called "Queens' Vases" served two primary and complementary functions during their object lives: they were vessels of propaganda and vessels of prestige. As vessels of propaganda, the faience oinochoai functioned as one of many material efforts initiated by the Ptolemies to radiate wealth and power throughout their sphere of influence. This propagandistic function of the vessels is well known, but the question of the possible owners of the jars - those who would have literally carried out the propagandistic message of the Ptolemies by carrying the vessels - has not been thoroughly investigated. Based on the provenance of the "Queens' Vases," especially the extra-Alexandrian examples, and their overall adornment and iconography, the owners are here suggested to be the mobile, upper-class elite of the Ptolemaic court, a group including, but by no means limited to, the eponymous priests of Alexander and the deified Ptolemies and the priestesses of Arsinoe Philadelphus at Alexandria, a number of whom were also upper-level military officers or the daughters of military officers. As vessels of prestige, the oinochoai were likely gifted or otherwise supplied to high-ranking functionaries by the royal house, and then displayed and/or used in cult rituals during the owner's lifetime, acting as visual signals of his or her proximity and loyalty to the Ptolemies. Finally, the vessels were buried with their owners as grave goods, thus ensuring that the prestige of the item was retained by the social group to which they were bestowed. ${ }^{8}$ For those functionaries whose hometowns were far from Alexandria, the vessels would have been transported abroad and buried with their owners. These two complementary and indeed, intertwined, goals of propaganda and prestige were achieved through the vessels' effective combination of aesthetics and multi-functionality. Re-situating the faience oinochoai

\footnotetext{
${ }^{8}$ For a discussion of the deliberate disposal of wealth as a "method of preserving the exclusivity of top-rank gifts" using the example of Archaic Greece, see Ian Morris, “Gift and Commodity in Archaic Greece.” Man, New Series, 21 (1) (1986) 1-17.
} 
within their contexts of display, use, diffusion, and ultimate deposition as luxury items, and proposing a restricted ownership among the Alexandrian elite, allows us to more fully appreciate the appearance of these vessels during the $3^{\text {rd }}$ century BCE.

\section{Brief history of interpretation}

The Ptolemaic oinochoai have received scholarly attention since at least the mid- $19^{\text {th }}$ century, ${ }^{9}$ most extensively in Dorothy Burr Thompson's seminal monograph, The Ptolemaic Oinochoai and Portraits in Faience (1973). Though Thompson concludes her study with the remark that, "The functions of the faience ritual vases...are still open to speculation," 10 her thorough cataloging and study of the vessels' iconography and inscriptions convincingly situates the vessels within the context of the Ptolemaic ruler cult. In particular, Thompson observes that the vessels were "highly standardized and expressly marked for the ruler-cult," and that the blended Egyptian, Greek and Persian design "is especially and brilliantly devised to publicize the virtues of the rulers."11 That the vessels' iconography and inscriptions directly relate to the ruler cult seems undeniable, and Thompson's link has been oft-repeated by scholars since the appearance of her monograph. Indeed, it is now well understood that the vessels would have been recognizable in Alexandria and elsewhere around the empire as relating to the Ptolemaic ruler cult.

Reviews of Thompson's monograph were largely positive, though the lack of a cohesive

picture of the vessels' ancient use(s) was frequently noted. ${ }^{12}$ As anticipated by Peck, ${ }^{13}$ following the publication of Thompson's study, a number of additional faience oinochoai and fragments have been published in museum and exhibition catalogues and other scholarly volumes, and new fragments occasionally appear in archaeological reports, though these typically brief

\footnotetext{
${ }^{9}$ E. Beulé, “Le vase de la reine Bérénice.” Journal des Savants (1862) 163-172.

${ }^{10}$ D.B. Thompson, Ptolemaic Oinochoai, 119.

11 Ibid.

${ }^{12}$ Reviews of D.B. Thompson, Ptolemaic Oinochoai and Portraits in Faience: Aspects of the Ruler Cult (1973) include: Erika Simon, Göttingische gelehrte Anzeigen 227 (1975) 206-216; Kate Bosse-Griffiths, Journal of Egyptian Archaeology 61 (1975) 291-292; Oswyn Murray, Journal of Hellenic Studies 96 (1976) 218-219; William H. Peck, Journal of Near Eastern Studies 36 (1) (1977) 73-74; A. N. Zadoks-Josephus Jitta, Mnemosyne, Fourth Series, 31 (2) (1978), 230-232; Antje Krug, Gnomon 50 (2) (1978) 195-200; Susan I. Rotroff, American Journal of Archaeology 83 (1979) 240-241.

13 JNES 36 (1) (1977), 73.
} 
entries rarely tackle the thorny issues of vessel function and ownership. ${ }^{14}$ Two exceptions to be noted are Niemeyer, who highlights the vessels' portability and multi-functionality in noting that, “Die Kannen, einmal gebraucht, konnten von den Besitzern einesteils wohl in die Tempel der zu Göttern erhobenen Herrscher gestiftet, anderenteils aber auch im privaten Haushalt aufbewahrt werden, um schliesslich als Beigabe mit ins Grab gegeben zu werden," ${ }^{15}$ and the Museumslandschaft Hessen Kassel's online presentation of an oinochoe said to be from Crete, which recognizes the jars' luxury status and likely elite ownership in remarking that "Solche Kannen waren wohl kostbare Geschenke des ägyptischen Herrscherpaares an ihre Verbündeten." 16

The relief images of the queens on the faience oinochoai have received perhaps the most scholarly attention to date, figuring frequently in art historical discussions of Alexandrian art and its diffusion in general, and Ptolemaic royal portraiture in specific. ${ }^{17}$ They have also been cited as examples of Ptolemaic royal propaganda. ${ }^{18}$ As for the vessels as a whole, despite their Greek form and iconography, they seem to fit well into Bianchi's definition of "luxury" or "deluxe" Egyptian faience, those objects "manufactured in institutionally affiliated workshops under the direction of administrators...hired by members of an elite that was dominated by the pharaoh [and who] were responsible for the manufacture of canonically sanctioned objects imbued with symbolism and meanings that were developed and understood by the elite."19

\footnotetext{
${ }^{14}$ See note 1 above.

${ }^{15}$ Niemeyer, “Eine Ptolemäerkanne aus Karthago,” 394-395.

16 http://www.museum-kassel.de/index_navi.php?parent=1357. Accessed May 29, 2013.

${ }^{17}$ The literature is extensive and cannot be fully cataloged here. See e.g. Robert S. Bianchi, “CAT. 68: Fragment of an Oinochoe with Berenike II Holding a Cornucopia.” Cleopatra's Egypt: Age of the Ptolemies. (Brooklyn: Brooklyn Museum, 1988) 174175; Arielle P. Kozloff, "Is There an Alexandrian style - What is Egyptian about It?." Alexandria and Alexandrianism. (Malibu: J. Paul Getty Museum, 1996) 247-258; Ibid., cat. no. 62, Gifts of the Nile: Ancient Egyptian Faience. Ed. Florence Dunn Friedman. (New York: Thames \& Hudson, 1998); Sally-Ann Ashton, Ptolemaic royal sculpture from Egypt: the interaction between Greek and Egyptian traditions. (Oxford: Archaeopress, 2001); Sabine Albersmeier, Untersuchungen zu den Frauenstatuen des ptolemäischen Ägypten. Aegyptiaca Treverenisa 10. (Mainz am Rhein: Verlag Philipp von Zabern, 2002); Wendy A. Cheshire, The Bronzes of Ptolemy II Philadelphus. Ägypten und Altes Testament 77. (München: Manfred Görg, 2009); Dimitris Plantzos, “The Iconography of Assimilation: Isis and royal imagery on Ptolemaic seal impressions.” More Than Men, Less Than Gods: Studies on Royal Cult and Imperial Worship. Proceedings of the International Colloquium Organized by the Belgian School at Athens (November 1-2, 2007). Studia Hellenistica 51. Eds. Panagiotis P. Iossif, Andrzej S. Chankowski and Cathatine C. Lorber (Leuven: Peeters, 2011) 389-415.

${ }^{18}$ D.B. Thompson, Ptolemaic Oinochoai, 120; Céline Marquaille, "The Foreign Policy of Ptolemy II.” Ptolemy II Philadelphus and his World. Mnenosyne Supplements 300. Eds. Paul McKechnie and Philippe Guillaume (Leiden: Brill, 2008) 39-64, esp. 58-60.

${ }^{19}$ Robert Steven Bianchi, “Symbols and Meanings.” In Florence Dunn Friedman, Gifts of the Nile: Ancient Egyptian Faience (New York: Thames and Hudson, 1998) 28.
} 
Indeed, most scholarly treatments implicitly regard the "Queens' Vases" as a special class of elite material culture, even if their elaboration and possible owners are rarely explicitly discussed.

What remains to be further explicated is how these special jars functioned, symbolically and practically, within the political and social milieu of the Ptolemaic empire. This may be achieved by reconsidering the vessels' decoration and contexts and asking who among the populace might have come into possession of these obviously regal items, and how exactly the jugs would have served their propagandistic purpose in the hands of these owners. Whereas Thompson suggests that the jugs were "used by the ordinary citizens as cheap substitutes for the gold or silver ritual vessels that must have been provided for the formal libation [of the ruler cult festival]," ${ }^{20}$ our review will affirm that the vessels were hardly "cheap," were not likely utilized by "ordinary citizens," and did not solely function in ruler cult festivities.

Before turning to the manufacture and decoration of the vessels, we should note that in addition to the overarching conclusion that the faience oinochoai were utilized for pouring libations during ruler cult festivals - the exact locations and procedures of which remain obscure $^{21}$ - Thompson also considers a variety of other possible uses for the vessels, including

${ }^{20}$ Ptolemaic Oinochoai, 75. The use of gold and silver vessels in the Grand Procession of the Ptolemaia festival is described by Callixenos of Rhodes (in Athenaeus, Deipnosophistae V, 197-203), so understanding the Ptolemaic oinochoai as ritual vessels made of a lesser-value material is not without merit. However, one must nuance the choice of faience for this corpus while also reconsidering the jars' intended owners. Regarding forerunners, Thompson and others see the Ptolemaic oinochoai as derived from metal predecessors - a model that has been proposed for other Hellenistic ceramics, including the so-called "Megarian bowls" manufactured at Athens - despite the fact that no metallic prototypes are known (Thompson, Ptolemaic Oinochoai, 14-15; Ellen D. Reeder, Hellenistic Art in the Walters Art Gallery [Baltimore: Trustees of the Walters Art Gallery, 1988], 103; on the "Megarian bowls" see Susan I. Rotroff, Hellenistic Pottery: Athenian and Imported Moldmade Bowls. The Athenian Agora XXII. [Princeton: American School of Classical Studies, 1982] and ibid., "The Introduction of the Moldmade Bowl Revisited: Tracking a Hellenistic Innovation." Hesperia: The Journal of the American School of Classical Studies at Athens 75 (3) (2006) 357-378.). Alternatively, Bianchi maintains that "The oinochoai themselves can be understood in terms of the development of Greek ceramics in general, and need not be indebted to any traditions in plate" (Cleopatra's Egypt, 174). Nenna sees both Achemenid metal and Greek ceramic predecessors for the larger corpus of Ptolemaic faience vessels, with metal vessels as potential sources for molds, and fired clay vessels as the inspiration for the closed forms (like the oinochoe) previously rare in Egypt. She perhaps best sums up the practical choice of faience for vessels like the Ptolemaic oinochoai with her observation that “La vaiselle en faïence apparaît comme un produit à double face. D'un côte, elle est un substitute moins onéreux des vases métalliques, de l'autre, elle offer des qualities esthétiques et techniques comme l'imperméabilité, supérieures à celles des céramiques.” (Marie-Dominique Nenna, "Les artisanats du verre et de la faïence: tradition et renouvellement dans l'Égypte gréco-romaine.” L'apport de l'Égypte à l'histoire des techniques. Bibliothèque d'Étude 142. (Cairo: Institut français d'archéologie orientale, 2006) 200-201.

${ }^{21}$ Stefan Pfeiffer summarizes the archaeological evidence for the ruler cult of Ptolemy II and Arsinoe II being performed inside the Serapieion at Alexandria, next to the sanctuary, as well as at Ptolemaic possessions further afield, while also noting that the dedicated sanctuary to the Theoi Adelphoi at Alexandria referred to by Herodas has yet to be identified: "The God Serapis.” Ptolemy II Philadelphus and His World. Mnemosyne Supplements 300. Eds. Paul McKechnie and Philippe Guillaume (Leiden: Brill, 2008) 398-408. See also D.B. Thompson, Ptolemaic Oinochoai, 71-75, 117-121; Georg Weber, "Ungleichheiten, Integration oder Adaptation? Der ptolemaïsche Herrscher- und Dynastiekult in griechische-makedonischer 
as prizes at festival games; as items presented by kings to courtiers in return for gifts given on celebratory occasions; as goods offered or sold to visitors or residents of Alexandria for use in the public ruler festival; as offerings dedicated to the ruler's temple; as items "taken... back home to bring luck or to be reused on suitable occasions;" and/or as jars utilized for the pouring of libations at altars set up in Alexandrian cemeteries. ${ }^{22}$ Thompson dismisses the first idea on the grounds that inscriptions on the oinochoai do not explicitly state a prize function, but leaves the remaining ideas open, acknowledging that " $[t]$ he presence of numerous oinochoai and fragments of faience in graves and cemeteries should also be explained." ${ }^{23}$ No single theory is put forth that would unify all of her proposed functions, nor has one emerged since, with the result that the vessels are still most often characterized as a class of object broadly related to ruler cult rituals, but whose exact social context remains unknown. ${ }^{24}$

Despite its frustrating lack of a cohesive conclusion, Thompson's study in fact makes a strong case for regarding the vessels as multifunctional luxury objects of royal dissemination. If one reads closely, one finds that a single context of use for the vessels is impossible to identify when considering their material, manufacture, iconography, inscriptions, and known or presumed findspots, nor, one might add, should a single context of use be expected for an ancient ceramic jug, even vessels as elaborate as these. The oinochoai are, at their most basic level, applicable to a variety of situations, and that is their brilliance: as lavishly decorated, yet still ostensibly functional jars, ${ }^{25}$ they are as appropriate for display and/or use during public festivities as they are for private libations or display at home or in cemeteries. Furthermore, they likely played a role in asserting their owner's prestige when included in the grave. Above all, what is lacking in Thompson's analysis is not one single scenario in which to situate the jars, for she does appear to recognize their wide applicability in public and private spheres, but an overt appreciation of their luxurious nature and likely elite ownership. In acknowledging the

Perspektive.” In Georg Weber, ed. Alexandreia und das ptolemäische Ägypten: Kulturbegegnungen in hellenistischer Zeit. (Berlin: Verlag Antike, 2010) 67.

22 Ptolemaic Oinochoai, 118-119.

${ }^{23}$ Ptolemaic Oinochoai, 119.

24 See most recently Weber, "Ungleichheiten, Integration oder Adaptation?,” 70 and Plantzos, “The Iconography of Assimilation," 390-391.

${ }^{25}$ As far as the author is aware, no residue of wine or other organic materials has been detected in or on the surviving oinochoai or fragments. 
combination of a multifunctional form with opulent decoration, one can begin to ask for whom such luxury vessels were produced, and through which mechanism(s) the vessels came to be so widely diffused, without the need to settle on any one situation in which the vessels were used, since public (festival), professional (priestly), private, and funerary uses are all equally as plausible.

While a funerary function for the vessels is the only one about which we can be absolutely certain given the vessels' predominant archaeological context and patterns of preservation, ${ }^{26}$ a deeper look into their materials and manufacture and geographic diffusion enables us to more fully appreciate the polyvalence - that is, the propagandistic and prestigious natures - of this special corpus, and thus better comprehend the vessels' likely roles in private and public venues during the $3^{\text {rd }}$ century BCE.

\section{Materials and Manufacture}

A few remarks are in order regarding the materials and stages of manufacture of the Ptolemaic oinochoai in order to highlight the prestige nature of the vessels. In observing the corpus as a whole, with its remarkable uniformity of material, size, shape, and decoration, one can readily see that the vessels were standardized, a signal that their design and manufacture received a royal imprimatur. ${ }^{27}$

The choice of faience for this group of vessels deserves special comment. As a quintessentially Egyptian substance that had been manufactured in Egypt for some three millennia by the time the Ptolemies took the throne, ${ }^{28}$ the bright, turquoise-colored ceramic was obviously selected for these vessels as a way to brightly and prominently reinforce the Ptolemies' ties to the land of Egypt and all of its political and material wealth. With its characteristic hue evocative of the freshness and fertility of the Nile, and its long tradition as a

\footnotetext{
${ }^{26}$ Both Thompson and Bianchi have remarked that the excellent state of preservation of the nearly complete oinochoai, many of which were found abroad, is suggestive of their deposition whole in a grave: Ptolemaic Oinochoai, 8; Cleopatra's Egypt, 175 n.2.

${ }^{27}$ Also noted by Thompson, Ptolemaic Oinochoai, 75, 119-120.

${ }^{28}$ Florence Dunn Friedman, “Faience: The Brilliance of Eternity,” in Friedman, ed. Gifts of the Nile, 16.
} 
royal luxury product, ${ }^{29}$ the bluish-green faience is here deployed in the creation of an entirely new type of vessel: a large, Greek-form wine jug decorated with Greek and Persian-style applied relief elements and Greek inscriptions relating to the royal cult. The combination of Egyptian material and Greek iconographic elements works to expertly broadcast both the jars' land of origin, and the kings' land of origin, symbolizing in one portable vessel the hybrid nature of the Ptolemaic kingdom. The vessels' materials and iconography further signal to observers that a jar's owner had been to Egypt, was connected to the royal court, and was thus placed at the highest levels of the international elite. As vessels of a material more challenging to manipulate than clay, ${ }^{30}$ and more brilliantly colored than even those of monochrome metal, the Ptolemaic faience oinochoai represent an age-old ceramic utilized in a wholly innovative manner.

As concerns the vessel type, the oinochoe, a Greek form also known as a chous, is a pitcher or jug characterized by a low-swung handle and a shoulder and body in one continuous curve. Averaging 30 centimeters in height and 15 centimeters in diameter, the Ptolemaic faience oinochoai are quite large compared to other contemporary faience vessels. ${ }^{31}$ With a capacity between two and three liters, the oinochoai were not intended as official units, but were rather a convenient size for pouring wine into a smaller drinking cup or offering dish, such as a phiale. ${ }^{32}$

In addition to being apparently functional as a wine jug, the choice of the oinochoe shape for this corpus constitutes a deliberate play on the relief scene depicted on the jars. Just moments before the scene depicted, in which a queen extends a phiale toward an altar, the dish in hand would have been filled with liquid poured from an oinochoe. The visual unity of vessel shape and relief decoration evokes not only the practical steps to be taken when pouring an offering but also, in including referents to the Ptolemaic ruler cult, provides the viewer with

\footnotetext{
${ }^{29}$ Robert Steven Bianchi, “Symbols and Meanings,” in Friedman, ed. Gifts of the Nile, 22-31; Diana Craig Patch, "By Necessity or Design: Faience Use in Ancient Egypt," in Friedman, ed. Gifts of the Nile, 32-45; Marian H. Feldman, Diplomacy by Design: Luxury Arts and an "International Style" in the ancient Near East, 1400-1200 BCE (Chicago: University of Chicago Press, 2006) 10, 30, 62, 100, 116-117.

30 Simon, review of Thompson, Ptolemaic Oinochoai, GGA 227 (1975) 207-208; Nenna, "Les artisanats du verre et de la faïence,” 200.

${ }^{31}$ Simon, review of Thompson, Ptolemaic Oinochoai, GGA 227 (1975) 207-208; Nenna, “Vaiselle en faïence,” 323.

32 D.B. Thompson, Ptolemaic Oinochoai, 13.
} 
an example the very situation in which a vessel owner would be expected to use, or display, his or her personal faience oinochoe. One might even say that the queen depicted on the vessel is demonstrating the appropriate use of the jar by pouring a libation for the deified Ptolemies, including her own divinized self.

Turning to the manufacture of the vessels, we find that the Ptolemaic oinochoai are the product of a multi-stage, multimedia and multi-artisan effort. The mouths, bodies, handles, base, relief scene, and Satyr and Silenus masks were formed and assembled using a complex piece-mold technique. As noted by Thompson, two to three molds, possibly made of plaster, would have been needed for the vessel body alone, with additional molds required for the base, handle, neck, trefoil mouth, Satyr and Silenus masks, and each element of the main relief scene, including separate molds for the altar, pillar, and queen's head, body, right arm, right hand holding the phiale, and left hand holding the cornucopia. Each of the above components would have been molded individually and then assembled, glazed in select locations, and fired. ${ }^{33}$ Marie-Dominique Nenna surmises that two types of artisans were required for the manufacture of the Ptolemaic oinochoai: faience experts who had mastered the material properties of the paste well enough to assemble these comparatively large vessels, and coroplasts to create molds for the various relief elements. ${ }^{34}$ It is likely that there were additional artisans involved in the detailed decorative work as well.

Adding to the vessels' complexity is the fact that, in addition to the faience paste and plaster or ceramic molds required to form the individual elements, two other substances were utilized in their manufacture, both of which required a supply of materials and skilled labor: polychrome glaze and gold leaf. While the craftsmen charged with preparing the faience paste may also have been charged with the addition of polychrome glaze to select relief elements, it is likely that another specialist or set of specialists was required for the preparation and application of gold leaf. Given the intricacy of the vessels' design and manufacture, their production undoubtedly occurred in a state-sponsored workshop setting. From the uniformity of the jars' decoration, to be discussed in more detail below, one can only presume that the

\footnotetext{
${ }^{33}$ D.B. Thompson, Ptolemaic Oinochoai, 13-16, 35.

${ }^{34}$ Nenna, "Varicella en faience," 323.
} 
craftsmen received direction regarding not only the layout of the main relief scene, ${ }^{35}$ but also the placement of polychrome and gold. Such direction could have been provided in the form of a template or sample vessel, if not verbal instructions. While the multimedia embellishments to the faience oinochoai are noted in detail in Thompson's catalogue, they have rarely factored into assessments of the vessels' potential ownership and use.

Before discussing the multimedia enhancement of the vessels in detail, however, we must briefly review the typical relief decoration of a Ptolemaic faience oinochoe, which can be reconstructed from our most complete examples. As noted, there are three main elements of the primary relief scene depicted on the front of the vessel, beneath the spout: (1) a queen sporting a 'melon' or a similarly fashionable hairstyle, wearing a royal fillet, stephane, or diadem, and clothed an elaborately pleated garment. The queen stands, looking to her right, while extending a phiale. In her left arm, she holds a cornucopia; in the case of Arsinoe II, the queen holds her trademark double cornucopia. (2) To the queen's right is an altar, often garlanded and sometimes inscribed. (3) To the queen's left is a tall, pointed, garlanded post, which has been identified as a cult pillar. ${ }^{36}$

Greek inscriptions incised on the shoulder of the jar prior to firing provide the name of a queen, in the genitive, together with one or more titles or divine associations, also in the genitive. In the case of vessels inscribed with the name of Ptolemy IV ("Basileus Ptolemaios"), only the epithet "Philopator" is given, and these inscriptions appear lower on the body of the vessel, in front of the standing queen (variously identified as Arsinoe III or Berenike II). ${ }^{37}$ Incised inscriptions also appear on some altars. On several jars inscribed with the name of Arsinoe II, the altar inscriptions repeat the wording above the scene, "Agathes Tyches Arsinoes Philadelphou," and add the name "Isis." On vessels naming Berenike II ("Basilisses Berenikes Agathes Tyches" or "Berenikes Basilisses Agathes Tyches"), inscribed altars bear the epithet of

\footnotetext{
35 The consistency of the spacing between the altar, figure and pillar in the main relief scene was noted by Thompson, who observed that "it must have been intended as part of the fundamental design": Ptolemaic Oinochoai, 69.

${ }^{36}$ D.B. Thompson, Ptolemaic Oinochoai, 62-67; Amy C. Smith, “Queens and Empresses as Goddesses: The Public Role of the Personal Tyche in the Graeco-Roman World.” An Obsession with Fortune: Tyche in Greek and Roman Art. Ed. Susan B. Matheson. (New Haven: Yale University Art Gallery, 1994) 89 and n.14.

37 D.B. Thompson, Ptolemaic Oinochoai, 87-91; Ashton, "Faience and the Ptolemaic royal cult," 334-336. Cheshire further observes that by this point, the image of the queen may have "degenerated into a more generalized type": The Bronzes of Ptolemy II Philadelphus, 176.
} 
the deified royal couple Berenike II and Ptolemy III, "Theoi Euergetai." None of the altars on jars bearing the name of Ptolemy IV are inscribed. ${ }^{38}$ These enigmatic inscriptions, with their curious use of the genitive, have proved vexing to scholars. In general, they can be understood as labels identifying the queen shown in the scene, as well as the deified royal family member(s) and associated deities to whom the libation in the scene - and perhaps the contents of the vessel and/or the vessel itself - are offered. ${ }^{39}$ The inscriptions are useful as dating criteria in that they provide a terminus post quem for each jar; they also likely play a role in demonstrating the propagandistic and prestigious nature of the vessels. Remarks on the relationship between the inscriptions, the vessels' geographic diffusion, and their possible ownership will be made below.

In addition to the main relief scene, the Ptolemaic oinochoai would also have had an applied Satyr mask just inside the mouth of the jar where the handle meets the mouth, and an applied Silenus mask at the bottom of the ribbed handle. As noted by Thompson, functionally, the masks were intended "to cover the transition from the handle to the body of the vase" while symbolically, in their Dionysiac form, they "must allude to the wine contained in the jug" as well as to ruler cult festivities. ${ }^{40}$ Both the Satyr and Silenus masks were framed by relief volutes representing the ends of the tainiai that bind the figures' foreheads. Additionally, four oinochoai fragments show molded wreaths around the neck of the vase. The base of the oinochoe, also separately shaped of faience, perhaps with the assistance of a wheel, was round and flat to allow the vessel to stand upright. $^{41}$

Returning to the multimedia aspect of the vessels, we can observe that numerous details of the main, high-relief offering scene - especially the queen's hair, eyebrows and pupils, the grapes and/or grain protruding from her cornucopia, and the garlands depicted on the altar and pillar - were often distinguished using a variety of colored glazes. Traces of glaze in the hues of black, brown, purple, dark blue, dark green, yellow, and red are all attested on the main relief scene as observed by Thompson and others. On some nearly complete

\footnotetext{
${ }^{38}$ D.B. Thompson, Ptolemaic Oinochoai, 19-22.

${ }^{39}$ D.B. Thompson, Ptolemaic Oinochoai, 19; Smith, “Queens and Empresses as Goddesses,” 89.

${ }^{40}$ D.B. Thompson, Ptolemaic Oinochoai,16, 41.

${ }^{41}$ D.B. Thompson, Ptolemaic Oinochoai, 13.
} 
oinochoai, as well as on a number of detached fragments, the hair, beard and/or eyes of Satyr and Silenus masks also exhibit traces of polychrome glaze. The inscriptions on the vessels can also appear darker owing to either added color or the pooling of the vitreous color inside the carved letters; this both enhances the coloristic effect of the vessel and increases the inscriptions' legibility. ${ }^{42}$ Though Thompson does not linger on the polychromatic aspect of the vessels when considering their potential uses, she does observe that, "The subordinate hues give the reliefs and heads a vividly pictorial character." 43 These careful additions of color to the figural and inscriptional aspects of the vessel should be recognized as both the work of an experienced, royally-sponsored workshop, and clear attempts to increase the sumptuousness of the jar and, by extension, the status of its owner.

As mentioned, in addition to the careful use of multicolored glazes, another material was often added to the vessels, and it is one that would have augmented their polychromatic appearance and social cachet exponentially: gold. Gilding or traces of it in the form of stippling are most often seen in the main relief scene, in particular on the edges of the queen's garment, on her fillet, stephane or diadem, on her arm bands and earrings, on the cornucopia, and on the phiale, as well as on the Satyr and Silenus masks and their accompanying relief decoration, and on the base of the pillar. ${ }^{44}$ Gilding is also attested on the lip, handle and base of vessels themselves, meaning that from nearly any angle, gilding would have been visible to an observer. This multimedia aspect of the Ptolemaic oinochoai literally highlights their luxury status. The addition of both gold leaf and polychrome glazes to an already bright, aquamarinecolored pitcher sporting a high-relief image of a Ptolemaic queen can only be understood as a deliberate effort to further increase the prestige of the vessel, with the concomitant result of augmenting the social standing of its bearer.

One particular example now at the Walters Art Museum in Baltimore will serve as a springboard from which we can appreciate this extensive and careful use of polychrome and

\footnotetext{
${ }^{42}$ D.B. Thompson, Ptolemaic Oinochoai, 12 and catalogue, passim.

${ }^{43}$ D.B. Thompson, Ptolemaic Oinochoai, 12.

${ }^{44}$ For high resolution images of oinochoai fragments featuring this type of gilding, see the Metropolitan Museum of Art online collections database for objects MMA 17.194.1697 and MMA 17.194.2392: https://www.metmuseum.org/art/collection/ search/250183 and https://www.metmuseum.org/art/collection/search/250524.
} 
gilding on the corpus of faience oinochoai. From the quantity and quality of surviving decoration on this fragment and others [See Tables 1 and 2], it is likely that these embellishments were part and parcel of each oinochoe at the moment it was created. Due to the fragility of the thin gold leaf, which was most likely applied post-firing, ${ }^{45}$ as well as the vessels' frequent deposition in graves, it is to be expected that many traces of gilding have been lost. ${ }^{46}$ Indeed, we are made sadly aware of the fragility of gold leaf in comparing E. Beulé's description of the faience oinochoe from Cyrene, now in Paris, ${ }^{47}$ with Thompson's description of the same vessel. Whereas Beule describes - with some reverence for the effect, one might note - the remains of gold on the pillar, phiale, queen's diadem, and upper edge of the queen's garment, ${ }^{48}$ Thompson reports only gilding on the hem of the queen's chiton and "yellowish on hair," ${ }^{49}$ the latter phrase perhaps pointing to the gilded diadem described by Beulé. From this example, one can appreciate just how much gilding must have flaked off of our surviving vessels and fragments from ancient times up to now. Fortunately, polychrome glaze, which most often would have been applied prior to firing, ${ }^{50}$ is more durable, and thus remains visible on a significant number of surviving fragments.

In describing the Baltimore oinochoe fragment in question, which preserves the upper portion of a high relief image of a queen, ${ }^{51}$ Dorothy Kent Hill notes that, "There seems to have been an elaborate and unusual color scheme. Black deposit on eye-brow, pupil of the eye, and hair, exclusive of band, is so carefully confined that we must suppose it was applied as an under-glaze coloring." ${ }^{52}$ In fact, this glazing pattern is not as unusual as Hill once surmised. Of the 267 nearly complete oinochoai and fragments described in Thompson's catalogue (the Baltimore fragment being one of them), almost one-third (93) bear traces of colored glaze,

\footnotetext{
${ }^{45}$ Cf. Marie Svoboda, “Decorative Gilding.” In Beth Cohen et. al., The Colors of Clay: Special Techniques in Athenian Vases (Los Angeles: J. Paul Getty Museum, 2006) 11-12; Jack Ogden, "Metals.” In Paul T. Nicholson and Ian Shaw, eds. Ancient Egyptian Materials and Technology (Cambridge and New York: Cambridge University Press, 2000) 164.

46 Thompson frequently notes the probability of original gilding when discussing individual relief components: Ptolemaic Oinochoai, 12, 15, 29, 42.

${ }^{47}$ Paris, Bibliothèque Nationale F 9083 (=D.B. Thompson, Ptolemaic Oinochoai, cat. no. 29).

${ }^{48}$ Beulé 1862: 167-168.

${ }^{49}$ Ptolemaic Oinochoai, 134.

${ }^{50}$ Paul T. Nicholson, with Edgar Peltenburg, “Egyptian Faience.” In Paul T. Nicholson and Ian Shaw, eds. Ancient Egyptian Materials and Technology (Cambridge and New York: Cambridge University Press, 2000) 187-188.

${ }^{51}$ Walters Art Museum 48.315 (=D.B. Thompson, Ptolemaic Oinochoai, cat. no. 5).

52 Dorothy Kent Hill, “Four Fragments of Ptolemaic High-Relief Faience,” Revue archéologique 43 (1954) 45.
} 
including at least 28 instances of dark glaze added to the queen's hair, eyebrow, or eyeball. One can also discern from these 93 examples several other color schemes, including some 14 examples of dark glaze - ranging in hue from dark blue to black - apparent on the hair, beards, and eyebrows of Satyr and Silenus masks; 31 instances of dark blue/purple added to the grapes hanging from the queen's cornucopia; six preserved examples of yellow added to stalks of grain projecting from the queen's cornucopia; and dark blue glaze on at least 11 altar or pillar garlands. [See Table 1] From Thompson and others' careful observations, ${ }^{53}$ and even from more general assessments, ${ }^{54}$ we can conclude that the careful addition of colored glaze to particular aspects of the figural elements was a common, likely standardized portion of the vessels' production.

Returning to the vessel fragment in Baltimore, Hill goes on to note that "There is no gilt present, but thick-set tiny dots in the glaze occur at exactly the places where, by analogy with similar fragments, one would expect gilding; in a band across the upper arm, in two streamers diverging from the back of the head, and along the chiton at the spectator's left." ${ }^{55}$ The "similar fragments" to which she refers are no doubt among the 32 additional oinochoai and fragments on which Thompson detected gilding or rough surfaces for the addition of gold leaf. [See Table 2] As noted above, among the extant examples of gilding on faience oinochoai, gold can be found on not only the main relief scene on the vessel, but also the Satyr and Silenus masks and their surrounding volutes, as well as the mouth, handle, and base of the vessel. From this pattern of preservation, one wonders whether the original aim was to outline the entire relief scene, and the entire vessel, in gold.

In summing up the color of the Ptolemaic oinochoai, Thompson remarks,

"In general, the faience objects must have been even livelier than they appear now, combining the virtues of relief ware with those of painting... The colour scheme of the jugs and figures was also vivid. They were originally a brilliant shining blue, gaily touched with deeper blue, green, yellow, purple, and considerable gold. They must have looked like relief paintings

\footnotetext{
${ }^{53}$ e.g. Kriseleit, "Fragmente von Ptolemäerkannen,” 62; Türkis und Azur: Quarzkeramik im Orient und Okzident, 369.

${ }^{54}$ e.g. Nenna and Seif el-Din, La vaisselle en faïence, 400: “Quelques touches de glaçure plus foncée, ou encore des feuilles d'or viennent souligner des details."

${ }^{55}$ Hill, "Four Fragments of Ptolemaic High-Relief Faience,” 45.
} 
and statuettes in silver, gold, and niello, exhibiting the taste for colour that was always intense among the people in the blinding light of Egypt." ${ }^{56}$

What is clear from a close inspection of the vessels' multimedia nature is that these faience jars were the product of an elaborate and exacting manufacturing process that required specialized skills and coordinated labor. It cannot be doubted that the intention of this highly standardized decorative scheme was to draw the eye to the vessel, and especially to its main relief scene, when the jar was displayed, carried and/or buried in view of others.

As has been recognized by art historians for some time, in their artistry, the Ptolemaic oinochoai are on par with the other genres of $3^{\text {rd }}$ century BCE material culture manufactured by and for the Alexandrian elite, including gold and silver vessels and jewelry, bronze and painted terracotta figurines, core-formed glass vessels, cameos and gems of semi-precious stone, and coins. $^{57}$ In accepting a luxury status for the Ptolemaic oinochoai, several of Thompson's suggestions regarding the vessels' acquisition, functions and ownership can be effectively dismissed. For example, her perception that the faience oinochoai were "a very minor product in a world far too civilized to have regarded them as of the slightest value ${ }^{158}$ should be rejected. Thompson's suggestion that these "trifles" 59 were sold or given to members of the lower classes and "used by the ordinary citizens as cheap substitutes for the gold or silver ritual vessels that must have been provided for the formal libation [of the ruler cult festival]" ${ }^{60}-a$ statement that has been periodically reiterated ${ }^{61}$ - should also be reconsidered. If we accept a luxury status for the vessels based on their material components, then we must re-situate their ownership as well, placing them firmly in the hands of the Alexandrian elite. We must also utilize their inscriptions and archaeological contexts in order to delve deeper into the role that the vessels' decoration and iconography played in the hands of their owners.

\footnotetext{
${ }^{56}$ D.B. Thompson, Ptolemaic Oinochoai, 12.

57 See e.g. Jeffrey Spier, “A Group of Ptolemaic Engraved Garnets.” The Journal of the Walters Art Gallery 47 (1989) 21-38; Arielle P. Kozloff, “Is There an Alexandrian Style - What Is Egyptian about It?” In Alexandria and Alexandrianism (Malibu: J. Paul Getty Museum, 1996) 247-260.

${ }^{58}$ Ptolemaic Oinochoai, 3.

59 Ibid.

${ }^{60}$ Ptolemaic Oinochoai, 75.

${ }^{61}$ See e.g. Ellen D. Reeder, Hellenistic Art in the Walters Art Gallery (Baltimore: Trustees of the Walters Art Gallery, 1988) 103; Kriseleit, “Fragmente von Ptolemäerkannen,” 62.
} 
$\underline{\text { Inscriptions and Geographic Distribution }}$

As noted above, the inscriptions incised on the shoulder of the jars and on the altars are all written in Greek. The upper inscriptions name a queen, either Arsinoe (II) or Berenike (II), or king Ptolemy (IV). In the case of Arsinoe II and Berenike II, their names appear in the genitive form accompanied by the phrase "Agathe Tyche," also in the genitive. This phrase has provoked considerable scholarly discussion, and a consensus has yet to be reached on its intention. Whereas Thompson and others have viewed the phrase as a reference to the "Good Fortune" or personal spirit of the individual queens, but not to a full-fledged deity, thus translating "Of the Good Fortune of [queen]," others have understood the phrase as referring to separate deities ("Of Good Fortune and of [queen]") or to a complete syncretization of the queen with the goddess Agathe Tyche or her broader manifestation, Tyche ("Of Agathe Tyche/ [queen]"). ${ }^{62}$ Others still have preferred to translate the upper inscription "For the good fortune" ${ }^{63}$ of the queen, an option that strays a bit from the genitive but is perhaps more fruitful for describing the aim of the ritual depicted on (and implied by) the jar.

As for the altar inscriptions, in the case of vessels inscribed with the name of Arsinoe II, the most complete versions repeat the name of the queen and the phrase "Agathe Tyche" in the genitive, and add the name "Isis" in the genitive as well. One can then translate "Of the Good Fortune of Arsinoe Philadelphos and of Isis," "Of Good Fortune, of Arsinoe Philadelphos and of Isis," or "Of the Good Fortune of Arsinoe Philadelphos/Isis." On vessels of Berenike II, altars are only inscribed with the phrase "Theoi Euergetai," referring to the deified brothersister rulers, Berenike II and Ptolemy III, known recipients of the ruler cult in their lifetimes. These altar inscriptions, thanks to their placement, more clearly indicate that the named individuals are the recipients of the offering that the queen is demonstrating, but unfortunately, they do little to illuminate the intended nature of "Agathe Tyche." However, they clearly add additional information regarding the scene at hand and the ruler cult at large

\footnotetext{
${ }^{62}$ Detailed histories of the inscriptions’ interpretation are provided by D.B. Thompson (Ptolemaic Oinochoai, 49-62), Murray in his review of Thompson's monograph (Journal of Hellenistic Studies 96 (1976) 218-219) and Smith ("Queens and Empresses as Goddesses," 89 and n.10-13). Note that Smith interprets the inscription as referring to both the tyche of the ruler and a syncretized divinity.

${ }^{63}$ E.g.“Oinochoe Depicting Berenike II.” The J. Paul Getty Museum Handbook of the Antiquities Collection. Second edition. Eds. Kenneth Lapatin and Karol B. Wight. (Los Angeles: J. Paul Getty Museum 2010) 99.
} 
by associating the queen with not just a Greek spiritual entity, but also the ancient and increasingly popular Egyptian goddess Isis, associations that were no doubt part and parcel of Ptolemy II's political propaganda. ${ }^{64}$

Whatever the exact nuances of the jars' inscriptions, which doubtless would have been obvious to an ancient owner, one may presume that all rulers pictured and/or named on the vessels - whether they were living and divinized at the time of vessel production, as seems to the case with Berenike II and Ptolemy III, and Arsinoe III and Ptolemy IV, or deceased and divinized, as with Arsinoe II - and all of the divine essences or goddesses referenced, are listed because they are the intended recipients of libations such as the one being made in the relief scene, and those that could be made via the jar itself. Whether Agathe Tyche, Isis and the queen are separate deities or syncretized elements of a deified queen (the latter interpretation being the most favored), the striking fact is that a queen's name is prominently, and in some cases repeatedly, placed in direct association with them on an elaborately decorated faience wine jar in Greek style that is of a functional, portable size. In text and in image - that is, in her association with Greek and Egyptian divine beings and in her semi-divine guise ${ }^{65}$ - the queen is clearly the focus of the oinochoai and thus any viewer's attention. The divinized queen is at once the enactor and the recipient of the offering being made in the scene. One might even say she is embodying the ruler cult ritual, reminding the viewer, and the jar's owner, of their obligation to pour libations for her and her associated divine aspects.

To summarize, the inscriptions and relief scene offer a glimpse into the early Ptolemaic conception of divine queenship and the rituals associated therewith, and are the strongest evidence that the faience oinochoai were intended to function as actual cult vessels for pouring offerings to the deified Ptolemies, especially the queens. However, the inscriptions signal more than a religious function for these luxury vessels; they also provide a hint as to the social role that the jars would have played in the hands of their owners. While the vessels' inscriptions unfortunately do not name the owners, they do suggest that the owners would have been elite,

\footnotetext{
${ }^{64}$ Marquaille, “The Foreign Policy of Ptolemy II,” 58-60; Kostas Buraselis, “The Problem of the Ptolemaic Sibling Marriage.” Ptolemy II Philadelphus and His World. Mnemosyne Supplements 300. Eds. Paul McKechnie and Philippe Guillaume (Leiden: Brill, 2008) 298.

${ }^{65}$ Smith, “Queens and Empresses as Goddesses,” 89-90.
} 
Greek-reading persons close to the court who were familiar with the nuances of the ruler cult and its requirements. One can presume that the vessels' owners were expected to demonstrate loyalty to the Crown and competence in official duties by enacting the type of libation suggested by the inscriptions and relief scene, by displaying the vessels publicly for others to see, and by taking them to other cities, where they would serve as a visual reminder of the Ptolemies' divine right to rule and material wealth. What the owner would receive in return is the recognition and prestige associated with possessing, displaying and utilizing such a royallyimprinted luxury vessel in view of others, including at their own burial, as well as the beneficence of the divine personnages to whom they literally or symbolically poured an offering by means of the jar. We may conclude that the Ptolemaic oinochoai, with their rich decoration featuring queens in an attitude of offering, and royal and divine names as apparent recipients, served as bright and colorful reminders of the fact that the Ptolemies, and especially the queens, were materially rich and politically influential semi-divine monarchs worthy of - and indeed, expecting to receive - liquid offerings from their subjects.

It is now apt to recall that faience oinochoai and fragments thereof have been recovered from a number of Egyptian sites outside of Alexandria, namely Bubastis (three examples), ${ }^{66}$ Canopus, ${ }^{67}$ Memphis (four examples), ${ }^{68}$ and Naukratis, ${ }^{69}$ and have been excavated at or are reported to be from a variety of sites outside of Egypt, namely Athens (nine fragments), ${ }^{70}$ Canosa (two examples), ${ }^{71}$ Carthage, $^{72}$ Corinth, $^{73}$ Crete (two examples), ${ }^{74}$

\footnotetext{
${ }^{66}$ Tübingen, Archäologisches Institut der Universitäts, 3778 (=D.B. Thompson, Ptolemaic Oinochoai, cat. no. 3), Amsterdam, Allard Pierson Museum 187 (=Thompson cat. no. 80), and Cairo, Egyptian Museum 9|11/22|8 (=Thompson, cat. no. 93).

${ }^{67}$ Alexandria Museum 18735 (=Thompson cat. no. 79).

${ }^{68}$ Cairo, Egyptian Museum CG 18026 (= Thompson cat. no. 26), Cairo, Egyptian Museum CG 18027 (=Thompson cat. no. 60), Cairo, Egyptian Museum JE 35643 (=Thompson cat. no. 92), Hildesheim, Pelizaeus-Museum Inv. Nr. 1185 (Busz and Gercke, eds. Türkis und Azur, cat. no. 214, 368-370).

${ }^{69}$ Oxford, Ashmolean Museum E 3720 (=Thompson cat. no. 19).

${ }^{70}$ Athens, Agora Museum P 22,906 (=Thompson cat. no. 27); see also http://www.agathe.gr/id/agora/object/p\%2022906; Athens, Agora Museum P 18,692 (=Thompson cat. no. 44); see also http://www.agathe.gr/id/agora/object/p\%2018692; Athens, Agora Museum G 25 (=Thompson, cat. no. 45); see also http://www.agathe.gr/id/agora/object/g\%2025, Athens, Agora Museum 8594 (=Thompson cat. no. 189); see also http://www.agathe.gr/id/agora/object/p\%208594; and Athens, Agora Museum P 6797 (=Thompson cat. no. 200); see also http://agathe.gr/id/agora/object/p\%206797. URLs accessed May 23, 2013.

${ }^{71}$ British Museum 1873,0820.389 (said to be from Canosa; purchased in 1873) (=Thompson cat. no.1) and British Museum GR 1856.12-26.192 (acquired in Italy, said to be from Canosa; bequeathed in 1856) (=Thompson cat. no. 87); see also http://www.britishmuseum.org/research/collection_online/collection_object_details.aspx?assetId=967226\&objectId=460427 \&partId=1 and http://www.britishmuseum.org/explore/highlights/highlight_objects/gr/a/a_queens_vase.aspx. URLs accessed May 23, 2013.

72 Inv. Ka 88/34-C1:3 and Inv. Ka 88/38-C1:2; Niemeyer, “Eine Ptolemäerkanne aus Karthago,” 391-395.
} 
Cyrene, ${ }^{75}$ Kourion (Cyprus), ${ }^{76}$ Samaria $^{77}$ and Xanthos, ${ }^{78}$ all being sites within the greater Ptolemaic empire. [See Figure 2]

Based on their provenance and "provincial quality,"79 Thompson tentatively identifies oinochoai and fragments from Cyrene, Crete, Memphis, and Bubastis as products of local manufacture (the Bubastis and Memphis examples perhaps all at Memphis). However, she goes on to note that stylistically, "those from Canopus, Naukratis, and Xanthos are surely among the finest products of the Alexandrian shops," and adds that examples "[o]f poorer Alexandrian work are those found in Italy and possibly the jug from Cyprus." 80 Thompson concludes that "It seems that most of the pieces found outside Egypt were carried there, presumably by travellers not exporters." ${ }^{81}$ While variations such as the "brownish" paste of the Benghazi example, ${ }^{82}$ the misspelled inscription on one Memphis example, ${ }^{83}$ the unusual relief elements on one Cretan example, ${ }^{84}$ and the lack of main relief elements on the Cypriot example ${ }^{85}$ are suggestive of manufacture outside of a closely-controlled environment, their size, material, and overall decorative program and embellishments are in keeping with the rest of the corpus. As definitive evidence for extra-Alexandrian production remains elusive, manufacture in Alexandria and

\footnotetext{
73 Corinth Museum MF 9245 (=Thompson cat. no. 179; “early Roman context.”); see also http://www.ascsa.net/id/corinth/object/c\%201947\%20938. Accessed May 29, 2013.

${ }^{74}$ Istanbul, Archaeological Museum (=Thompson cat. no. 112); Kassel, Museumslandschaft Hessen Kassel Antikensammlung T 1018, allegedly from Lasaia, Crete (Busz and Gercke, eds. Türkis und Azur, cat. no. 212, 368-370); see also http://www.museum-kassel.de/index_navi.php?parent=1357. Accessed May 29, 2013.

${ }^{75}$ Paris, Bibliothèque Nationale F 9083 (=Thompson cat. no. 29); Beulé 1862.

${ }^{76}$ Cambridge, Corpus Christi College CCC/LV 9 (=Thompson cat. no. 141); see also Penelope Wilson, “Cat. No. 212.” In Vassos Karageorghis, Eleni Vassilika and Penelope Wilson, The Art of Ancient Cyprus in the Fitzwilliam Museum, Cambridge (Cambridge: Fitzwilliam Museum and Nicosia: A.G. Leventis Foundation, 1999) 128-9, and http://data.fitzmuseum.cam.ac.uk/id/object/89347. Accessed May 29, 2013.

${ }^{77}$ Harvard Excavations at Samaria Reg. No. 4862, S11 z, October 15, 1910; George Reisner, Harvard excavations at Samaria, 1908-1910 (Cambridge, MA: Harvard University Press, 1924) 326; Parlasca, JDAI 91 (1976) 146 and n.69.

78 Antalya Museum 571 (=Thompson cat. no. 75); Pierre Demargne and Henri Metzger, "Note sur les travaux à Xanthos en 1951.” In Comptes-rendus des séances de l'Académie des Inscriptions et Belles-Lettres, 95e année, n. 4, 1951, 345-346; Pierre Demargne, Fouilles de Xanthos I: Les Piliers Funéraires. Paris: Librairie C. Klincksieck, 1958, 47-58.

${ }^{79}$ Ptolemaic Oinochoai, 107.

${ }^{80}$ Ibid.

${ }^{81}$ Ibid.

${ }^{82}$ Paris, Bibliothèque Nationale F 9083 (=Thompson cat. no. 29); Ptolemaic Oinochoai, 10-11.

${ }^{83}$ Cairo, Egyptian Museum JE 35643 (=Thompson cat. no. 92); Ptolemaic Oinochoai, 22.

${ }^{84}$ Istanbul, Archaeological Museum (=Thompson cat. no. 112); Ptolemaic Oinochoai, 39.

${ }^{85}$ Cambridge, Corpus Christi College CCC/LV 9 (=Thompson cat. no. 141); see also http://www.fitzmuseum.cam.ac.uk/explorer/index.php?oid=89347.
} 
subsequent diffusion by individual transport remains the preferred scenario for the majority of faience oinochoai found outside of the Ptolemaic capital.

Probable Owners

Unfortunately we do not have personal names or titles attached to any of the faience oinochoai or fragments, so we cannot assign ownership of a particular oinochoe to a known individual, although Greek-reading and speaking owners are to be inferred from the language of the vessels' inscriptions. It may, however, be possible to link the vessels to at least one particular set of Alexandrian elites utilizing the jars' extra-Alexandrian findspots. In considering how these opulent jars could have arrived at cities distant from the capital yet within the Ptolemaic sphere, we must inquire which categories of professionals would have been close enough to the royal court to warrant both a visit to Alexandria and the acquisition of a gilded jar of royal manufacture, as well as mobile enough to bring such a prized possession back to their hometown for eventual burial, and savvy enough to comprehend the message conveyed by an embellished faience pitcher. Put another way, we must consider that the owners of our faience oinochoai found abroad were professionals whose duties included physically coming to Alexandria for a period of time, and envision that it was during such a stint that these individuals would have acquired this special kind of vessel, perhaps as an emblem of office and/or as a gift from the royal family. The faience oinochoai found abroad must have been kept in an individual's possession until their return home, whereupon they were likely displayed in public and certainly interred as burial goods.

One class of $3^{\text {rd }}$ century Ptolemaic officials that meets these criteria for royal patronage, extra-Egyptian residences, and seagoing mobility, are the eponymous priests and priestesses of the ruler cult, about whom we have a certain amount of documentary evidence. As Clarysse has observed, "The great majority of the eponymous priests comes from the Ptolemaic empire: Samos, Crete, Lycia, Cyrene, Palestine, Cyprus are all part of the kingdom." 86 Further, these same eponymous priests were often selected from the upper echelons of the military, while some daughters of army officers were appointed eponymous priestesses of the cult of Arsinoe

\footnotetext{
${ }^{86}$ Clarysse, “Ethnic Diversity and Dialect,” 10.
} 
II (kanephoros). ${ }^{87}$ In addition, "in more than one case the same person or members of the same families" simultaneously held the offices of eponymous priest and eponymous officer, a distinct honor for a member of the mobile elite. ${ }^{88}$ These appointments may be regarded as strategic moves by "a Hellenistic king who built his authority on his capacity as a military leader." ${ }^{89}$ Given the international makeup of this elite military class, we can infer that these officials traveled between their hometowns and Alexandria at least once, but probably rather frequently, during in their careers. One would imagine that attendance at the four-yearly Ptolemaia festival - the grandest of which included not only processions dedicated to the deified royal ancestors and Dionysus, gymnastic and equestrian events, and lavish displays of a royal accouterments, but also the presence of delegates from Greek cities and a sizeable parade of military personnel ${ }^{90}$ was a requirement of office, in addition to participation in regularly-scheduled ruler cult activities and military endeavors.

Furthermore, we are well informed of the fact that the eponymous priests of Alexander and the deified Ptolemies were compelled to maintain the image and cult of the rulers at sites outside of Alexandria through deeds such as the erection of commemorative statues and inscriptions, the founding of festivals, and the dedication of offerings. ${ }^{91}$ As observed by Marquaille, the eponymous priests' "proximity to the royal house entitled them to act as representatives of the king abroad, but also [shows] that their functions in Alexandria could not be separated from their function in the empire." ${ }^{92}$ These civic and religious obligations of the priests, and the concomitant opportunities to travel between their hometowns and Alexandria, would have well placed them in a position to acquire, and subsequently utilize and display, an elaborate faience oinochoe, thereby meeting both the Ptolemies' need to exert their influence outside of Egypt, and the individual's own need to gain or reinforce their prestige at home.

\footnotetext{
${ }^{87}$ Clarysse, "Ethnic Diversity and Dialect,” 10; W. Peremans and E. Van ‘t Dack, "Notes sur quelques prêtres eponymes.” Historia 8 (1959) 170.

${ }^{88}$ Clarysse, "Ethnic Diversity and Dialect,” 11-12.

${ }^{89}$ Marquaille, “The Foreign Policy of Ptolemy II,” 45.

${ }^{90}$ Paul Goukowsky, “The pomp of the Ptolemies.” Alexandria, third century BC. Eds. Christian Jacob and François de Polignac; translated by Colin Clement (Alexandria, Egypt: Harpocrates Publishing, 2000) 136-141; Marquaille, "The Foreign Policy of Ptolemy II," 41, 54-58.

${ }^{91}$ Marquaille, “The Foreign Policy of Ptolemy II,” 60-61.

${ }^{92}$ Marquaille, “The Foreign Policy of Ptolemy II,” 61.
} 
When one maps the actual or presumed extra-Egyptian provenances of faience oinochoai and the international origins of eponymous priests, one finds a certain amount of overlap [Figure 3]. To cite a few examples, one of our best preserved faience jars, an oinochoe inscribed for Berenike II and the Theoi Euergetai, was excavated at Xanthos, ${ }^{93}$ a Lycian city under direct Ptolemaic control from the reign of Ptolemy II Philadelphus to 197 BCE and indeed, a city praised by Ptolemy III for its allegiance to the Ptolemaic king, including the sending of theoroi (ambassadors) to the Ptolemaia festival. ${ }^{94}$ According to the 1958 excavation report, the oinochoe was found in an intact Hellenistic burial situated inside the so-called "Sarcophagus Pillar," a $3^{\text {rd }}$ century BCE funerary monument erected on the Lycian acropolis. The Hellenistic burial inside the pillar was itself covered by a late $6^{\text {th }}$ century BCE relief slab depicting wrestlers, which had once decorated a dynastic pillar tomb in the vicinity. ${ }^{95}$ Mixed together with scattered bones and two skulls were the faience oinochoe, a faience phiale, and numerous other goods indicative of a high-status burial, including: fragments of a Hadra vase, two calcite vessels, numerous fragments of iridescent glass vessels and a vessel mouth of opaque blue glass with traces of white paint, two bronze mirrors, seven gold pendants in the shape of laurel leaves, a gold filigree pendant embellished with green stones, and a gold ring. ${ }^{96}$ Unfortunately, the decedents are nowhere named. However, the grave goods serve a clear indication of the prominence and relative wealth of the deceased.

We may note that Xanthos is the hometown of at least one eponymous priest, Tlepolemus, son of Artapates, a descendant of Persian dynasts in Lycia who was an Olympic victor in the colt race in 256 and was appointed eponymous priest of Alexander and the deified Ptolemies in 247/6 and 246/5, thus straddling the reigns of Ptolemy II and III; he then served as a high Ptolemaic official in Caria during the Third Syrian War. ${ }^{97}$ Even though Tlepolemus was in

\footnotetext{
${ }^{93}$ Antalya Museum 571 (=Thompson cat. no. 75: “The finest surviving oinochoe.”).

${ }^{94}$ Marquaille, “The Foreign Policy of Ptolemy II,” 55-56 n. 74.

${ }^{95}$ Demargne, Fouilles de Xanthos I: Les Piliers Funéraires, 47-58; Antony G. Keen, "The Dynastic Tombs of Xanthos: Who Was Buried Where?” Anatolian Studies 42 (1992) 54 n.5, 57 fig. 1, 62.

96 Demargne and Metzger, “Note sur les travaux à Xanthos en 1951,” 345-346; Demargne, Fouilles de Xanthos I, $54-58$ and pl. XIV-XVI.

97 Willy Clarysse and Griet Van der Veken, with the assistance of S.P. Vleeming, The Eponymous Priests of Ptolemaic Egypt. Papyrologica Lugduno-Batava 24. (Leiden: Brill 1983) 8-10; Willy Clarysse, "Ethnic Diversity and Dialect Among the Greeks of Hellenistic Egypt.” In The Two Faces of Graeco-Roman Egypt: Greek and Demotic and Greek-Demotic Texts and
} 
office as eponymous priest a few years prior to the introduction of the epithet Theoi Euergetai for the ruling couple in $243 / 2,{ }^{98}$ it is not impossible that, as a religious and administrative official known to Ptolemy III, he could have been the recipient of this jar - and thus the owner of the Sarcophagus Pillar tomb - perhaps acquiring the oinochoe on a visit to Alexandria in recognition of his service and/or attendance at the Ptolemaia. Further, given the elaboration of the monument and the sumptuousness of the burial from which the Xanthos oinochoe derives, as well as the tomb's clear physical and iconographic association with the city's dynastic heritage, it is obvious that the owner of the vessel was an individual of the same background, status and courtly access as Tlepolemus, if not Tlepolemus himself - a "grand personnage de la Xanthos ptolémaïque, qu'on voulut enterer auprès des dynastes," as observed by Demargne. ${ }^{99}$ In considering this identification of Tlepolemus as the owner of the Xanthos oinochoe, it is also relevant to note that the connection between Lycia and the office of the eponymous priesthood was already well established by Tlepolemus' time, as two priests of Lycian extraction are documented for the mid-third century under Ptolemy II: Aetos of Aspendos, who served as eponymous priest in 253/252 and adopted Alexandrian citizenship, and his successor, Neoptolemos, son of Kraisis, (252/251), a Ptolemaic strategos whose defense of the local town of Tlos against the Pisidians, Galatians and Thracians was commemorated with a statue in the sanctuary of the founders. ${ }^{100}$

Other locations from which derive both faience oinochoai and eponymous priests and priestesses of the third century include Athens, Crete, Cyprus, and Benghazi. The nine fragments of faience oinochoai excavated at the Athenian Agora range in date from the reign of Ptolemy II to that of Ptolemy IV, according to Thompson, and all derive from either cistern/drain or fill contexts, making it impossible to tie them to an individual context or

Studies presented to P.W. Pestman. Eds.A.M.F.W. Verhoogt and S.P. Vlemming. (Leiden: Brill, 1998) 8-9; Walter Ameling, "Tlepolemus." Brill's New Pauly (2012). http://referenceworks.brillonline.com/entries/brill-s-new-pauly/tlepolemuse1216290\#e1216320. Accessed May 29, 2013.

${ }^{98}$ D.B. Thompson, Ptolemaic Oinochoai, 149-150.

${ }^{99}$ Fouilles de Xanthos I, 59.

${ }^{100}$ Clarysse and Van der Veken, The Eponymous Priests of Ptolemaic Egypt, 8; Clarysse, “Ethnic Diversity and Dialect,” 7; "Neoptolemus." Brill's New Pauly. (2012). http://referenceworks.brillonline.com/entries/brill-s-new-pauly/neoptolemuse820040. Accessed May 29, 2013. 
owner. ${ }^{101}$ Athens was, however, the hometown of Glaukon, eponymous priest of Alexander and the deified Ptolemies in 255/254, an Olympic victor in the four-horse chariot race in 282/1 who was also honored by the king in a decree at Platea for his contributions to the cult of Zeus Eleutherios and Homonia. ${ }^{102}$

Crete, home of Tlepolemos' predecessor, Antiochos, eponymous priest of Alexander and the deified Ptolemies in 248/47 and eponymous Ptolemaic officer from 262-243/2, and Matela, daughter of Androkades, kanephoros of Arsinoe Philadelphus in 259/258, ${ }^{103}$ has also provided us with two examples of faience oinochoai. ${ }^{104}$ One of these jars, an uninscribed vessel now in Istanbul whose main relief scene is preserved in several large fragments, exhibits some unique iconographic features (e.g. a goat advancing toward the right from behind the altar). ${ }^{105}$ Thompson has tentatively assigned this oinochoe's manufacture to a local workshop and dated it to the reign of Ptolemy IV. ${ }^{106}$ This Cretan jar may be an imitation of an earlier, more typical Ptolemaic oinochoe once seen by a local resident and whose imagery was both replicated and expanded upon to produce a unique exemplar. As imitation can be an indicator of an object's perceived high value and prestige status, regarding this oinochoe as an imitation of an Alexandrian original would reinforce the perception of the vessels' prestige at sites abroad.

The faience oinochoe from Kourion, Cyprus, is another unusual example that, while bearing an inscription with the name of Ptolemy IV and applied masks and shoulder garland, lacks a main relief scene. ${ }^{107}$ Thompson is undecided as to the location of its manufacture,

\footnotetext{
${ }^{101}$ See above n.70.

102 Clarysse and Van der Veken, The Eponymous Priests of Ptolemaic Egypt, 8; Clarysse, “Ethnic Diversity and Dialect,” 7; Marquaille, “The Foreign Policy of Ptolemy II," 57, 61, esp. n.83; the dedication to Glaukon has been variously attributed to Ptolemy I, II or III.

${ }^{103}$ Clarysse and Van der Veken, The Eponymous Priests of Ptolemaic Egypt, 6-8; Clarysse, “Ethnic Diversity and Dialect,” 7-8; "Antiochus." Brill's New Pauly (2012). http://referenceworks.brillonline.com/entries/brill-s-new-pauly/antiochus-e124580. Accessed May 29, 2013.

${ }^{104}$ Istanbul, Archaeological Museum (=Thompson cat. no. 112); Kassel, Museumslandschaft Hessen Kassel Antikensammlung T 1018, allegedly from Lasaia, Crete (Busz and Gercke, eds. Türkis und Azur, cat. no. 212, 368-370); see also http://www.museum-kassel.de/index_navi.php?parent=1357. Accessed May 29, 2013.

${ }^{105}$ Istanbul, Archaeological Museum (=Thompson cat. no. 112); D.B. Thompson, Ptolemaic Oinochoai, 39, 161-162, and Pls. XXXIX-XL

${ }^{106}$ Ptolemaic Oinochoai, 107, 162.

${ }^{107}$ Cambridge, Corpus Christi College CCC/LV9 (=Thompson cat. no. 141); see also also Penelope Wilson, “Cat. No. 212.” In Vassos Karageorghis, Eleni Vassilika and Penelope Wilson, The Art of Ancient Cyprus in the Fitzwilliam Museum, Cambridge (Cambridge: Fitzwilliam Museum and Nicosia: A.G. Leventis Foundation, 1999) 128-9 and http://data.fitzmuseum.cam.ac.uk/id/object/89347. Accessed May 29, 2013.
} 
alternately characterizing it as being "of poorer Alexandrian work" and "possibly...a cheap provincial example," suggesting that it was fashioned "under special circumstances that prevented its receiving the usual reliefs." ${ }^{108}$ Similarly, Penelope Wilson remarks that "the whole jug gives the impression of being carelessly made, perhaps in haste" and notes that the place of manufacture was "probably Alexandria." ${ }^{109}$ As this jar retains the typical shape, size, material, inscription, and relief masks of the corpus at large, but lacks the main relief scene, for which numerous molds were required, it may in fact be an extra-Alexandrian work. If so, then it is nevertheless an effective one, in that it is clearly recognizable as belonging to this special class of luxury vessels. Furthermore, not unlike the burial from which the Xanthos jar derives, the tomb from which this vessel was excavated also contained a glass cup and a gold collar or ring ("bague") with an engraved (gem) stone, giving a clear indication of the decedent's wealth and access to luxury goods. ${ }^{110}$ The one eponymous priest known to be of Cypriot origin, Ptolemaios son of Ptolemaios, was appointed in 215/4, during the reign of Ptolemy IV. ${ }^{111}$

Lastly, the well-preserved, through unprovenanced, faience oinochoe from Benghazi inscribed for Berenike $\mathrm{II}^{112}$ brings to mind the Cyreneans Menekrateia, daughter of Philammon, who served as kanephoros of Arsinoe Philadelphus from July 239 to July 237, and Eukles, son of Eubatas, who served as eponymous priest of Alexander and the deified Ptolemies for 236/235. ${ }^{113}$ Given the relatively high number of eponymous priests of Samian and Rhodian origin appointed during the third century (four and five, respectively), ${ }^{114}$ one would not be surprised if fragments of Ptolemaic oinochoai emerge from those islands in the future.

To summarize, while the majority of faience oinochoai fragments derive from Alexandria, in particular its Hellenistic cemeteries, a number of examples, including some of our best preserved vessels, have been found throughout the Mediterranean, a diffusion that must

\footnotetext{
${ }^{108}$ D.B. Thompson, Ptolemaic Oinochoai, 107, 171.

109 “Cat. No. 212,” The Art of Ancient Cyprus in the Fitzwilliam Museum, Cambridge, 128.

${ }^{110}$ Robert Mowat, “Chronique.” Bulletin épigraphique VI (1886) 100.

${ }^{111}$ Clarysse and Van der Veken, The Eponymous Priests of Ptolemaic Egypt, 16; Clarysse, "Ethnic Diversity and Dialect,” 8.

112 Paris, Bibliothèque Nationale F 9083 (=D.B. Thompson, Ptolemaic Oinochoai, cat. no. 29).

${ }^{113}$ Clarysse and Van der Veken, The Eponymous Priests of Ptolemaic Egypt, 6-7, 12; Clarysse, “Ethnic Diversity and Dialect,” 78.

${ }^{114}$ Clarysse, “Ethnic Diversity and Dialect,” 7-10.
} 
be considered when reconstructing their potential ownership. While none of the faience oinochoai found abroad are inscribed for their owner, and while only the Xanthos example derives from a context that has allowed it to be tentatively linked to a particular individual, the geographic overlap of the vessels' extra-Egyptian provenances and the homelands of numerous eponymous priests and priestesses, as well as the sumptuousness of several of the burials from which these jars derive, is nevertheless suggestive of this class of functionaries being one of the no doubt several groups of elite courtiers to whom such jars were distributed.

In conclusion, we have observed that in their size, materials, stages of manufacture, and decoration, the Ptolemaic faience oinochoai were standardized, luxury vessels most likely produced in a royal workshop in Alexandria, with some examples having been transported abroad by individual owners, and others perhaps imitated at cities distant from the capital. We have suggested that given their bright coloring and prominent visual and textual allusions to the Ptolemaic ruler cult, these vessels were suitable for both practical use in religious rituals in Alexandria and abroad, and private use as treasured possessions, including deposition in the grave. We have argued that as sumptuous objects featuring gilding, royal iconography, and Greek inscriptions, the Ptolemaic oinochoai were most likely distributed to high elites of the court who were familiar with the nuances of the ruler cult and charged with its promotion. It has been proposed that the Ptolemaic oinochoai would have simultaneously functioned as propagandistic objects intended to reinforce the piety, legitimacy, and wealth of the Ptolemies abroad, and prestige items capable of augmenting the social standing of the owner, whether in Alexandria or overseas, though perhaps the vessels were at their most powerful abroad.

The eponymous priests of Alexander and the deified Ptolemies and the eponymous priestesses of Arsinoe II at Alexandria, about whom we happen to be quite well informed, are one class of international, mobile elites who may have owned such faience oinochoai. It may therefore be possible to put the vessels back into the hands of some of their owners, and reconstruct their journey to sites abroad, from acquisition in Alexandria, to use in religious ceremonies in Egypt and abroad, to eventual interment in a grave. The latter practice would ensure that the prestige associated with owning such a jar remained with the individual in 
perpetuity. In reassessing these vessels through all of their material and archaeological aspects, we come to the conclusion that they were hardly the "trifles" or "cheap substitutes" once theorized by Thompson. Rather, the Ptolemaic oinochoai were a triumph of Ptolemaic propaganda and material culture, for they at once broadcasted the rulers' message of divine leadership through a portable object of sumptuous materials, while at the same time making the broadcasters feel privileged, honored, and prestigious to be part of the system. 


\section{Figures}

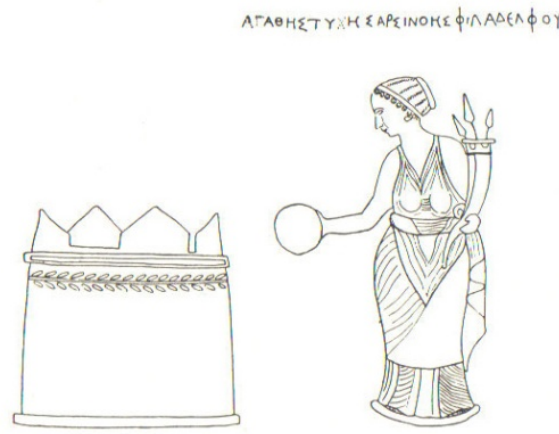

No. I

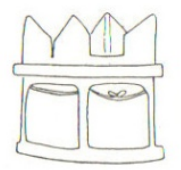

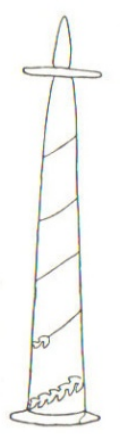

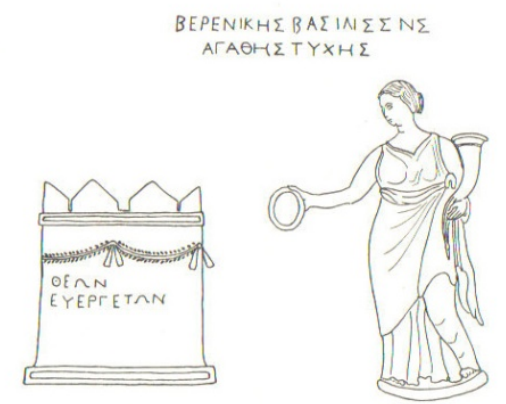

No. 75
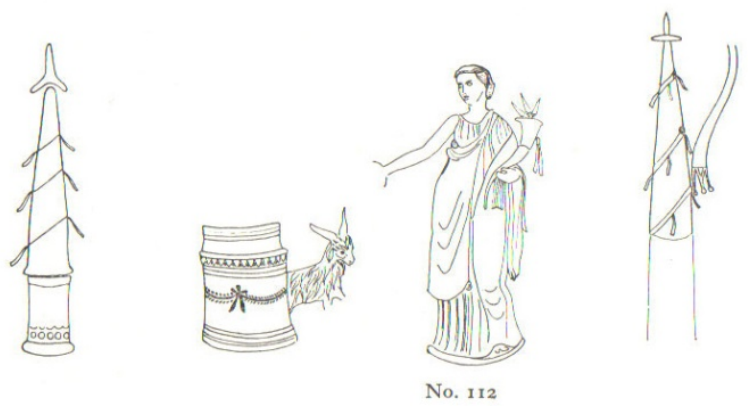

FiG. 2. Scenes on Oinochoai. (Scale $\mathrm{I}: 3$ )

Figure 1: Line drawings depicting four examples of the main relief scene on faience oinochoai. After D.B. Thompson, The Ptolemaic Oinochoai and Portraits in Faience. Oxford: Clarendon Press, 1973, FIG. 2. 


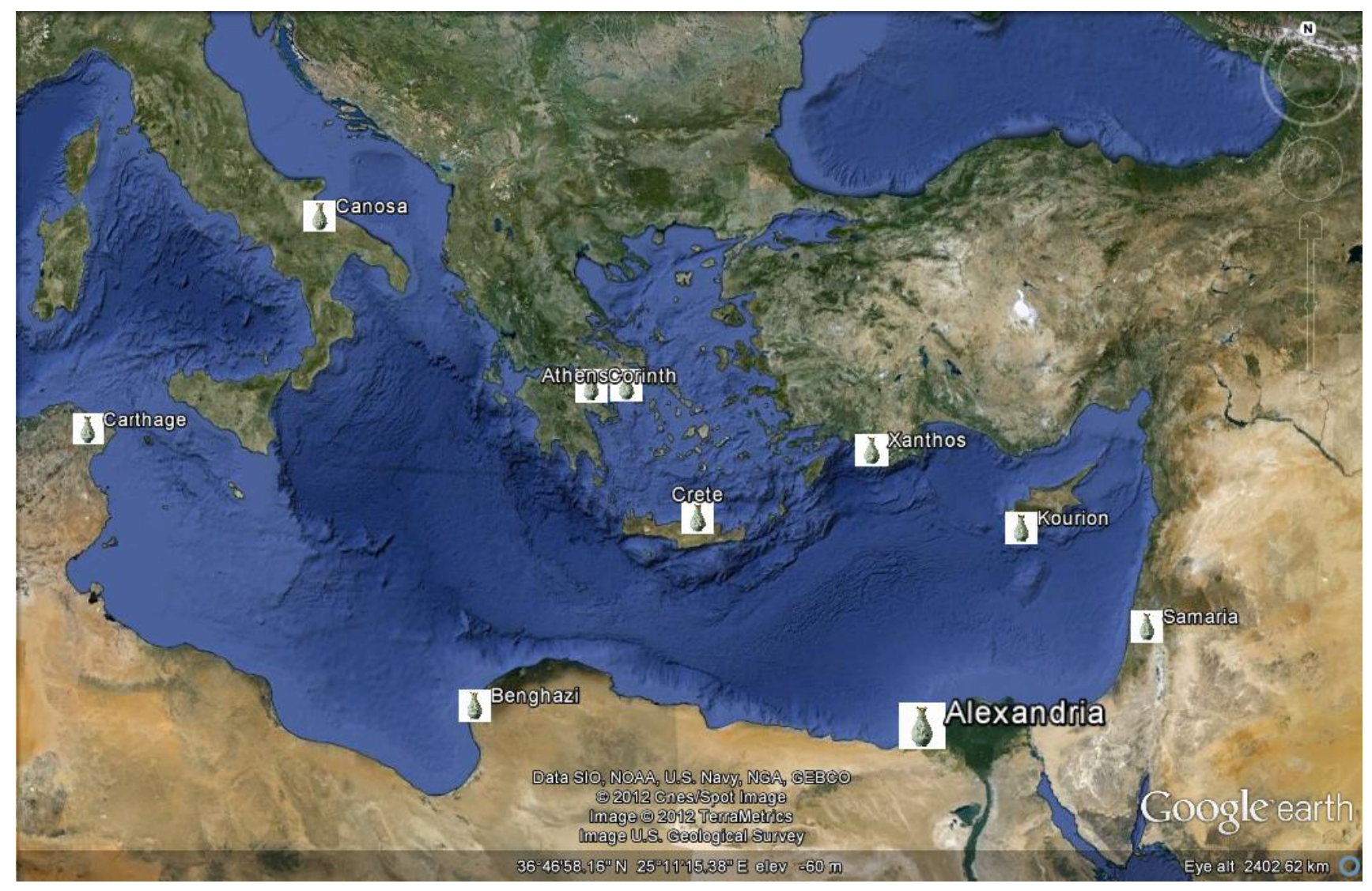

Figure 2: Google earth map showing the actual and presumed extra-Egyptian findspots of faience oinochoai, in relation to the Ptolemaic capital. Illustration by the author. 


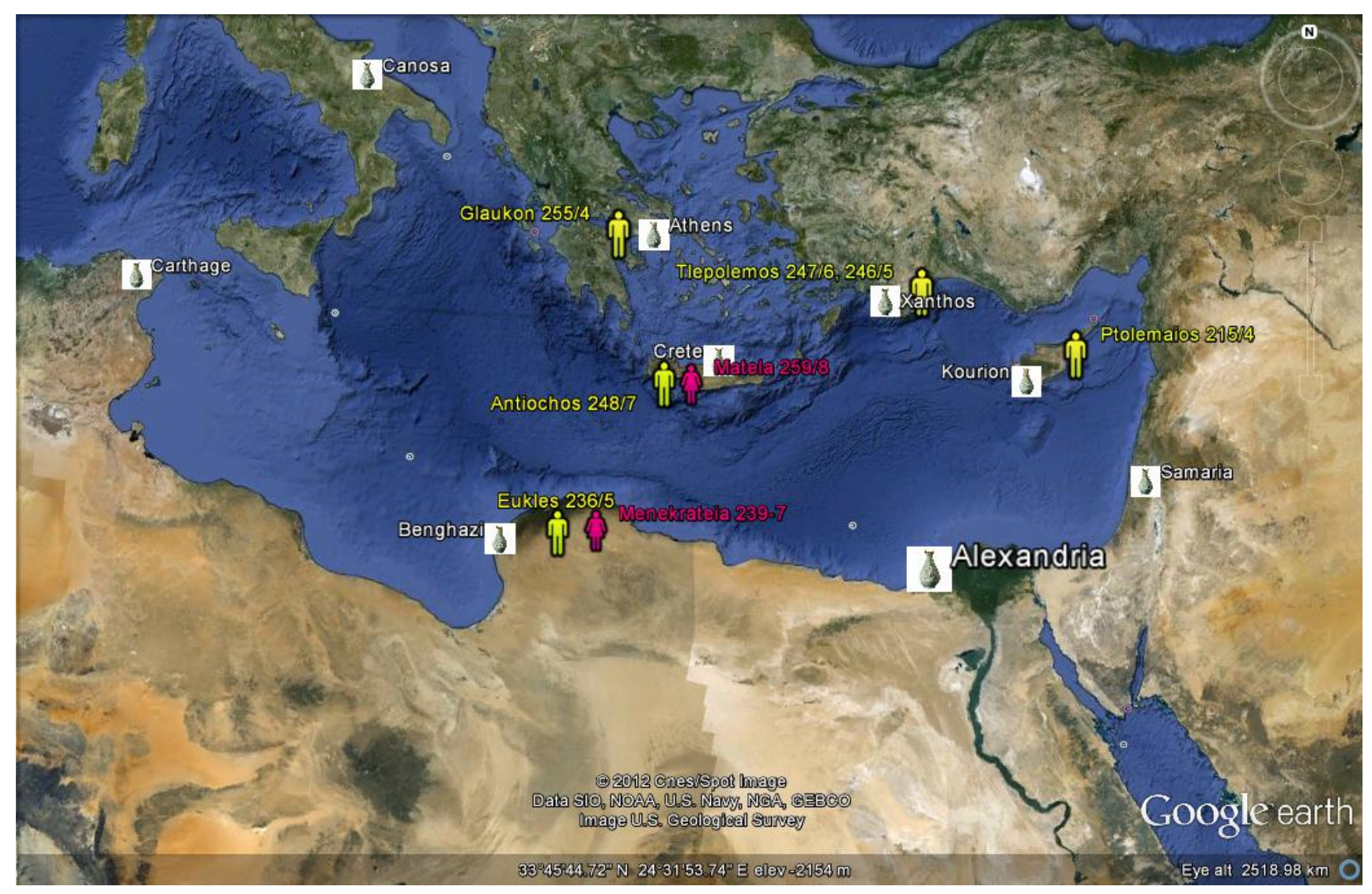

Figure 3: Google earth map showing the geographical overlap between foreign eponymous priests and priestesses of the Ptolemaic ruler cult and actual or presumed extra-Egyptian findspots of faience oinochoai. Illustration by the author. 
Table 1: Oinochoai and fragments of oinochoai featuring colored glaze as reported in the catalogue of Dorothy Burr Thompson, The Ptolemaic Oinochoai and Portraits in Faience (1973)

\begin{tabular}{|c|c|c|c|c|}
\hline $\begin{array}{l}\text { Thompson } \\
\text { cat. no. }\end{array}$ & Provenance & Museum no. & $\begin{array}{l}\text { Hue(s) and } \\
\text { location of } \\
\text { glaze }\end{array}$ & Additional remarks \\
\hline 1 & $\begin{array}{l}\text { Said to be from } \\
\text { Canosa } \\
\text { (purchased in } \\
1873 \text { ) }\end{array}$ & $\begin{array}{l}\text { London, British } \\
\text { Museum } \\
1873,0820.389\end{array}$ & $\begin{array}{l}\text { Dark* } \\
\text { coloring on } \\
\text { hair, brows } \\
\text { of satyr, and } \\
\text { of queen; } \\
\text { purple on } \\
\text { grapes. }\end{array}$ & $\begin{array}{l}\text { *Note that the term "dark" is } \\
\text { frequently employed by } \\
\text { Thompson as a general description } \\
\text { of added glaze that may be black, } \\
\text { brown, blue, purple, or green in } \\
\text { color. } \\
\text { For this vessel, see also } \\
\text { http://www.britishmuseum.org/re } \\
\text { search/collection online/collectio } \\
\text { n object details.aspx?assetld=967 }\end{array}$ \\
\hline 2 & Unprovenanced & $\begin{array}{l}\text { Munich, } \\
\text { Antikensammlung } \\
8720\end{array}$ & $\begin{array}{l}\text { Dark on eye } \\
\text { and brow of } \\
\text { queen }\end{array}$ & \\
\hline 4 & Alexandria & $\begin{array}{l}\text { Athens, National } \\
\text { Museum M } 1326\end{array}$ & $\begin{array}{l}\text { Dark on } \\
\text { grapes }\end{array}$ & \\
\hline 5 & Unprovenanced & $\begin{array}{l}\text { Baltimore, Walters } \\
\text { Art Museum } 48.315\end{array}$ & $\begin{array}{l}\text { Per } \\
\text { Thompson: } \\
\text { "thick black } \\
\text { overglaze } \\
\text { on [queen's] } \\
\text { hair, brow, } \\
\text { eye." }\end{array}$ & $\begin{array}{l}\text { Note that Hill (1954: 45) regards } \\
\text { the glaze as an under-glaze: } \\
\text { "Black deposit on eye-brow, } \\
\text { pupil of the eye, and hair, } \\
\text { exclusive of band, is so carefully } \\
\text { confined that we must suppose } \\
\text { that it was applied as an under- } \\
\text { glaze coloring;" }\end{array}$ \\
\hline 8 & $\begin{array}{l}\text { Alexandria, Kom } \\
\text { el-Shugafa }\end{array}$ & $\begin{array}{l}\text { Alexandria Museum } \\
5815\end{array}$ & $\begin{array}{l}\text { Per } \\
\text { Thompson: } \\
\text { "Added dark } \\
\text { (green) on } \\
\text { drapery." }\end{array}$ & \\
\hline 16 & $\begin{array}{l}\text { Alexandria, } \\
\text { Chatby }\end{array}$ & $\begin{array}{l}\text { Alexandria Museum } \\
\text { 18869a }\end{array}$ & $\begin{array}{l}\text { Dark on } \\
\text { grapes }\end{array}$ & \\
\hline 17 & $\begin{array}{l}\text { Alexandria, } \\
\text { Chatby }\end{array}$ & $\begin{array}{l}\text { Alexandria Museum } \\
19293\end{array}$ & $\begin{array}{l}\text { Dark on } \\
\text { grapes, } \\
\text { green on } \\
\text { grain }\end{array}$ & \\
\hline 21 & $\begin{array}{l}\text { Alexandria, } \\
\text { Hadra }\end{array}$ & $\begin{array}{l}\text { Alexandria Museum } \\
5544\end{array}$ & $\begin{array}{l}\text { Dark on } \\
\text { grapes }\end{array}$ & \\
\hline 22 & Egypt & $\begin{array}{l}\text { Athens, National } \\
\text { Museum, } \\
\text { Demetriou }\end{array}$ & $\begin{array}{l}\text { Dark on } \\
\text { eyes, hair of } \\
\text { queen }\end{array}$ & \\
\hline
\end{tabular}




\begin{tabular}{|c|c|c|c|c|}
\hline & & Collection 2678 & & \\
\hline 25 & $\begin{array}{l}\text { Probably } \\
\text { Alexandria }\end{array}$ & $\begin{array}{l}\text { New York, } \\
\text { Metropolitan } \\
\text { Museum of Art } \\
\text { 26.7.1016 }\end{array}$ & $\begin{array}{l}\text { Per } \\
\text { Thompson: } \\
\text { "added dark } \\
\text { overglaze } \\
\text { on hair, } \\
\text { brows, eyes } \\
\text { [of queen]." }\end{array}$ & $\begin{array}{l}\text { See also } \\
\text { http://www.metmuseum.org/Coll } \\
\text { ections/search-the- } \\
\text { collections/100009159?rpp=20\&p } \\
\mathrm{g}=1 \& \mathrm{ft}=26.7 .1016 \& \mathrm{pos}=1\end{array}$ \\
\hline 28 & $\begin{array}{l}\text { Alexandria, } \\
\text { Chatby }\end{array}$ & $\begin{array}{l}\text { Alexandria Museum } \\
15936\end{array}$ & $\begin{array}{l}\text { Dark on } \\
\text { grapes }\end{array}$ & \\
\hline 28 bis & Unprovenanced & $\begin{array}{l}\text { Bonn, Akademisches } \\
\text { Kunstmuseum } 1281\end{array}$ & $\begin{array}{l}\text { Dark on } \\
\text { grapes }\end{array}$ & \\
\hline 29 & $\begin{array}{l}\text { Benghazi } \\
\text { (acquired 1859) }\end{array}$ & $\begin{array}{l}\text { Paris, Bibliothèque } \\
\text { Nationale F } 9083\end{array}$ & $\begin{array}{l}\text { Per } \\
\text { Thompson: } \\
\text { "Yellowish } \\
\text { on hair." }\end{array}$ & \\
\hline 30 & Alexandria & $\begin{array}{l}\text { Paris, Louvre AM } \\
1847\end{array}$ & $\begin{array}{l}\text { Per } \\
\text { Thompson: } \\
\text { "Yellowish } \\
\text { colour on } \\
\text { hair and } \\
\text { brows" }\end{array}$ & \\
\hline 31 & Unprovenanced & $\begin{array}{l}\text { Paris, Louvre AM } \\
1463\end{array}$ & $\begin{array}{l}\text { Yellow on } \\
\text { grain, } \\
\text { purple on } \\
\text { grapes }\end{array}$ & \\
\hline 32 & Alexandria & $\begin{array}{l}\text { Bern, O. and L. } \\
\text { Havenith Collection }\end{array}$ & $\begin{array}{l}\text { Dark on } \\
\text { grapes and } \\
\text { [queen's] } \\
\text { hair, yellow } \\
\text { on grain } \\
\end{array}$ & \\
\hline 36 & $\begin{array}{l}\text { Alexandria, } \\
\text { Hadra }\end{array}$ & $\begin{array}{l}\text { Alexandria Museum } \\
16595\end{array}$ & $\begin{array}{l}\text { Purple } \\
\text { grapes }\end{array}$ & \\
\hline 37 & Alexandria & $\begin{array}{l}\text { Alexandria Museum } \\
\text { T } 47\end{array}$ & $\begin{array}{l}\text { Purple on } \\
\text { grapes }\end{array}$ & \\
\hline 42 & Alexandria & $\begin{array}{l}\text { Stuttgart, } \\
\text { Württembergisches } \\
\text { Landesmuseum } 166\end{array}$ & $\begin{array}{l}\text { Dark blue } \\
\text { on garlands, } \\
\text { spikes of } \\
\text { horn, grapes }\end{array}$ & \\
\hline 44 & $\begin{array}{l}\text { Athens, Agora } \\
\text { Excavations } \\
\text { deposit M 21:1 } \\
\text { (late third to } \\
\text { early second c. } \\
\text { BCE) }\end{array}$ & $\begin{array}{l}\text { Athens, Agora } \\
\text { Museum P } 18692 \\
\text { (five fragments) }\end{array}$ & $\begin{array}{l}\text { Dark on } \\
\text { queen's hair }\end{array}$ & \\
\hline 55 & Alexandria & $\begin{array}{l}\text { Alexandria Museum } \\
\text { T } 14\end{array}$ & $\begin{array}{l}\text { Yellow on } \\
\text { bracelet }\end{array}$ & \\
\hline
\end{tabular}




\begin{tabular}{|c|c|c|c|c|}
\hline 56 & Alexandria & $\begin{array}{l}\text { Alexandria Museum } \\
\text { T } 16\end{array}$ & $\begin{array}{l}\text { Yellow on } \\
\text { grain, } \\
\text { purple on } \\
\text { grapes }\end{array}$ & \\
\hline 58 & Unprovenanced & $\begin{array}{l}\text { Vienna, } \\
\text { Kunsthistorisches } \\
\text { Museum Inv. V } 2019\end{array}$ & $\begin{array}{l}\text { Per } \\
\text { Thompson: } \\
\text { "Dark } \\
\text { yellow } \\
\text { underglaze } \\
\text { on [queen's] } \\
\text { hair, brow; } \\
\text { purple } \\
\text { grapes." }\end{array}$ & \\
\hline 62 & Alexandria & $\begin{array}{l}\text { Athens, Benaki } \\
\text { Museum } 12584\end{array}$ & $\begin{array}{l}\text { Dark blue } \\
\text { on grapes }\end{array}$ & \\
\hline 63 & $\begin{array}{l}\text { Athens } \\
\text { (acquired 1837) }\end{array}$ & $\begin{array}{l}\text { New York, } \\
\text { Metropolitan } \\
\text { Museum of Art } \\
\text { 17.1914.1697 }\end{array}$ & $\begin{array}{l}\text { Dark on } \\
\text { grapes }\end{array}$ & $\begin{array}{l}\text { See also } \\
\text { http://www.metmuseum.org/Coll } \\
\text { ections/search-the- } \\
\text { collections/130010663?rpp=20\&p } \\
\mathrm{g}=1 \& \mathrm{ft}=17.194 .1697+\& \mathrm{pos}=1\end{array}$ \\
\hline 64 & $\begin{array}{l}\text { Alexandria, } \\
\text { Hadra }\end{array}$ & $\begin{array}{l}\text { Alexandria Museum } \\
19294\end{array}$ & $\begin{array}{l}\text { Dark on } \\
\text { grapes }\end{array}$ & \\
\hline 66 & Unprovenanced & $\begin{array}{l}\text { Alexandria Museum } \\
16171\end{array}$ & $\begin{array}{l}\text { Purple on } \\
\text { grapes }\end{array}$ & \\
\hline 68 & $\begin{array}{l}\text { Alexandria, } \\
\text { Chatby }\end{array}$ & $\begin{array}{l}\text { Alexandria Museum } \\
18868\end{array}$ & $\begin{array}{l}\text { Dark on } \\
\text { queen's hair }\end{array}$ & \\
\hline 69 & Unprovenanced & $\begin{array}{l}\text { Oxford, Ashmolean } \\
\text { Museum 1892.1025 }\end{array}$ & $\begin{array}{l}\text { Per } \\
\text { Thompson: } \\
\text { "Dark, } \\
\text { underglaze, } \\
\text { on [queen's] } \\
\text { hair, } \\
\text { grapes." }\end{array}$ & \\
\hline 72 & Alexandria & $\begin{array}{l}\text { Athens, National } \\
\text { Museum M } \pi 1335\end{array}$ & $\begin{array}{l}\text { Purple on } \\
\text { grapes }\end{array}$ & \\
\hline 73 & Alexandria & $\begin{array}{l}\text { Alexandria Museum } \\
5547\end{array}$ & $\begin{array}{l}\text { Dark on } \\
\text { grapes }\end{array}$ & \\
\hline 74 & $\begin{array}{l}\text { Alexandria, } \\
\text { Chatby }\end{array}$ & $\begin{array}{l}\text { Alexandria Museum } \\
19344\end{array}$ & $\begin{array}{l}\text { Purple on } \\
\text { grapes }\end{array}$ & \\
\hline 75 & Xanthos, Lycia & $\begin{array}{l}\text { Antalya Museum } \\
571\end{array}$ & $\begin{array}{l}\text { Per } \\
\text { Thompson: } \\
\text { “Dark on } \\
\text { [queen's] } \\
\text { hair, green } \\
\text { on garlands, } \\
\text { altar } \\
\text { mouldings, }\end{array}$ & $\begin{array}{l}\text { Per Demargne (1958, } 54-55) \text { : "les } \\
\text { cheveux sont peints en noir, un } \\
\text { large bandeau garde la couleur de } \\
\text { la glaçure...la main droite posée à } \\
\text { plat sur le flanc du vase présente } \\
\text { une patère à omphalos central en } \\
\text { direction d'un autel." }\end{array}$ \\
\hline
\end{tabular}




\begin{tabular}{|c|c|c|c|c|}
\hline & & & $\begin{array}{l}\text { letters." } \\
\text { Also, the } \\
\text { queen's } \\
\text { phiale } \\
\text { "shows } \\
\text { traces of } \\
\text { painted } \\
\text { design, } \\
\text { petals or } \\
\text { rays from an } \\
\text { omphalos?" }\end{array}$ & \\
\hline 76 & Unprovenanced & $\begin{array}{l}\text { Cairo, Egyptian } \\
\text { Museum } 13|3 / 34| 1 \\
\text { (seven fragments) }\end{array}$ & $\begin{array}{l}\text { Greenish on } \\
\text { grapes, altar } \\
\text { moulding, } \\
\text { garland on } \\
\text { pillar }\end{array}$ & \\
\hline 87 & $\begin{array}{l}\text { Said to be from } \\
\text { Canosa } \\
\text { (Acquired in } \\
\text { Italy, } \\
\text { bequeathed to } \\
\text { museum in } \\
1856 \text { ) }\end{array}$ & $\begin{array}{l}\text { London, British } \\
\text { Museum GR } \\
\text { 1856.12-26.192 } \\
\text { (Vases K 76) }\end{array}$ & $\begin{array}{l}\text { Dark blue } \\
\text { on altar } \\
\text { fillets }\end{array}$ & \\
\hline 90 & $\begin{array}{l}\text { Alexandria, } \\
\text { Hadra }\end{array}$ & $\begin{array}{l}\text { Alexandria Museum } \\
5542\end{array}$ & $\begin{array}{l}\text { Traces of } \\
\text { dark on } \\
\text { queen's hair }\end{array}$ & \\
\hline 93 & $\begin{array}{l}\text { Zagazig } \\
\text { (Bubastis) }\end{array}$ & $\begin{array}{l}\text { Cairo, Egyptian } \\
\text { Museum } 9|11 / 22| 8\end{array}$ & $\begin{array}{l}\text { Dark on } \\
\text { grapes }\end{array}$ & \\
\hline 101 & $\begin{array}{l}\text { Alexandria, } \\
\text { Chatby }\end{array}$ & $\begin{array}{l}\text { Alexandria Museum } \\
18869\end{array}$ & $\begin{array}{l}\text { Dark on } \\
\text { queen's } \\
\text { eyeballs, } \\
\text { small trace } \\
\text { on grapes } \\
\end{array}$ & \\
\hline 102 & $\begin{array}{l}\text { Alexandria, } \\
\text { Hadra }\end{array}$ & $\begin{array}{l}\text { Alexandria Museum } \\
5728\end{array}$ & $\begin{array}{l}\text { Brown on } \\
\text { queen's } \\
\text { brows, hair; } \\
\text { dark on } \\
\text { trace of } \\
\text { grapes }\end{array}$ & \\
\hline 107 & Alexandria & $\begin{array}{l}\text { Alexandria Museum } \\
5546\end{array}$ & $\begin{array}{l}\text { Dark on } \\
\text { queen's hair }\end{array}$ & \\
\hline 108 & $\begin{array}{l}\text { Alexandria, } \\
\text { Chatby }\end{array}$ & $\begin{array}{l}\text { Alexandria Museum } \\
19343\end{array}$ & $\begin{array}{l}\text { Dark on } \\
\text { grapes }\end{array}$ & \\
\hline 109 & $\begin{array}{l}\text { Said to be from } \\
\text { Lower Egypt }\end{array}$ & $\begin{array}{l}\text { Baltimore, Walters } \\
\text { Art Museum } 48.309\end{array}$ & $\begin{array}{l}\text { Dark on } \\
\text { queen's hair }\end{array}$ & $\begin{array}{l}\text { Cf. Hill (1954:46): "The dark } \\
\text { material in the hair seems to be } \\
\text { merely an acretion [sic] of dirt." }\end{array}$ \\
\hline 112 & Crete & Istanbul, & Dark on & \\
\hline
\end{tabular}




\begin{tabular}{|c|c|c|c|c|}
\hline & & $\begin{array}{l}\text { Archaeological } \\
\text { Museum } \\
\text { (two large joining } \\
\text { fragments) }\end{array}$ & $\begin{array}{l}\text { queen's } \\
\text { hair, brows, } \\
\text { eyeballs }\end{array}$ & \\
\hline 115 & Alexandria & $\begin{array}{l}\text { Amsterdam, Allard } \\
\text { Pierson Museum } \\
7582 \text { (von Bissing } \\
\text { Collection F 863) }\end{array}$ & $\begin{array}{l}\text { Dark on } \\
\text { grapes and } \\
\text { queen's } \\
\text { hair, yellow } \\
\text { on spikes of } \\
\text { grain }\end{array}$ & \\
\hline 116 & Unprovenanced & $\begin{array}{l}\text { Per Thompson: } \\
\text { "Present } \\
\text { whereabouts } \\
\text { unknown. Formerly } \\
\text { in Thompson } \\
\text { Collection, } \\
\text { Princeton (from } \\
\text { Abemayor, New } \\
\text { York, 1963; stolen } \\
\text { 1964)." }\end{array}$ & $\begin{array}{l}\text { Dark on } \\
\text { queen's hair } \\
\text { and on } \\
\text { grapes }\end{array}$ & \\
\hline 118 & Alexandria & $\begin{array}{l}\text { Athens, National } \\
\text { Museum M } 1325\end{array}$ & $\begin{array}{l}\text { Dark on } \\
\text { queen's hair }\end{array}$ & \\
\hline 122 & Alexandria (?) & $\begin{array}{l}\text { Alexandria Museum } \\
16170\end{array}$ & $\begin{array}{l}\text { Dark on } \\
\text { grapes }\end{array}$ & \\
\hline 123 & Unprovenanced & $\begin{array}{l}\text { Oxford, Ashmolean } \\
\text { Museum } 1909.347\end{array}$ & $\begin{array}{l}\text { Dark blue } \\
\text { on queen's } \\
\text { hair and } \\
\text { grapes, } \\
\text { yellow on } \\
\text { spikes of } \\
\text { grain }\end{array}$ & \\
\hline 125 & $\begin{array}{l}\text { Alexandria, } \\
\text { Chatby }\end{array}$ & $\begin{array}{l}\text { Alexandria Museum } \\
15940\end{array}$ & $\begin{array}{l}\text { Yellow fruit, } \\
\text { green stalks } \\
\text { of grain }\end{array}$ & \\
\hline 126 & $\begin{array}{l}\text { Probably } \\
\text { Alexandria }\end{array}$ & $\begin{array}{l}\text { New York, } \\
\text { Metropolitan } \\
\text { Museum of Art } \\
\text { 26.7.1017 }\end{array}$ & $\begin{array}{l}\text { Dark blue } \\
\text { overglaze } \\
\text { on queen's } \\
\text { hair, brow } \\
\text { and eyeball }\end{array}$ & $\begin{array}{l}\text { See also } \\
\text { http://www.metmuseum.org/Coll } \\
\text { ections/search-the- } \\
\text { collections/100009159?rpp=20\&p } \\
\mathrm{g}=1 \& \mathrm{ft}=26.7 .1016 \& \mathrm{pos}=1\end{array}$ \\
\hline 127 & $\begin{array}{l}\text { Alexandria, } \\
\text { Chatby }\end{array}$ & $\begin{array}{l}\text { Alexandria Museum } \\
19356\end{array}$ & $\begin{array}{l}\text { Dark blue } \\
\text { underglaze } \\
\text { on queen's } \\
\text { hair, brow }\end{array}$ & \\
\hline 128 & $\begin{array}{l}\text { Alexandria, } \\
\text { Chatby }\end{array}$ & $\begin{array}{l}\text { Alexandria Museum } \\
16258\end{array}$ & $\begin{array}{l}\text { Dark blue } \\
\text { on queen's } \\
\text { hair and } \\
\text { brow }\end{array}$ & \\
\hline
\end{tabular}




\begin{tabular}{|c|c|c|c|c|}
\hline 129 & Unprovenanced & $\begin{array}{l}\text { Seattle Art Museum } \\
\text { Eg. } 24.5\end{array}$ & $\begin{array}{l}\text { Dark blue } \\
\text { overglaze } \\
\text { on hair and } \\
\text { eyeball }\end{array}$ & $\begin{array}{l}\text { Thompson notes that "Head has } \\
\text { been cut into a roundel in modern } \\
\text { times" and "Hair may have been } \\
\text { repainted, along with very wide } \\
\text { tainia. Traces of thin fillet seem } \\
\text { visible through applied paint." }\end{array}$ \\
\hline 130 & $\begin{array}{l}\text { Alexandria, } \\
\text { Chatby }\end{array}$ & $\begin{array}{l}\text { Alexandria Museum } \\
19357\end{array}$ & $\begin{array}{l}\text { Dark on } \\
\text { queen's hair }\end{array}$ & \\
\hline 132 & Unprovenanced & $\begin{array}{l}\text { Alexandria Museum } \\
23948\end{array}$ & $\begin{array}{l}\text { Brownish } \\
\text { underglaze } \\
\text { on queen's } \\
\text { hair }\end{array}$ & \\
\hline 133 & Alexandria & $\begin{array}{l}\text { Athens, National } \\
\text { Museum M } 1333\end{array}$ & $\begin{array}{l}\text { Dark blue } \\
\text { underglaze } \\
\text { on queen's } \\
\text { hair }\end{array}$ & \\
\hline 138 & Alexandria & $\begin{array}{l}\text { Alexandria Museum } \\
5724\end{array}$ & $\begin{array}{l}\text { Dark } \\
\text { (turned to } \\
\text { green) on } \\
\text { queen's hair }\end{array}$ & \\
\hline 139 & $\begin{array}{l}\text { Alexandria, } \\
\text { Chatby }\end{array}$ & $\begin{array}{l}\text { Alexandria Museum } \\
18240\end{array}$ & $\begin{array}{l}\text { Dark blue } \\
\text { added in } \\
\text { lettering of } \\
\text { inscriptions, } \\
\text { queen's hair }\end{array}$ & \\
\hline 143 & $\begin{array}{l}\text { Alexandria, } \\
\text { Chatby }\end{array}$ & $\begin{array}{l}\text { Alexandria Museum } \\
16516\end{array}$ & $\begin{array}{l}\text { Traces of } \\
\text { dark blue in } \\
\text { letters }\end{array}$ & \\
\hline 146 & Alexandria & $\begin{array}{l}\text { Alexandria Museum } \\
\text { T } 32\end{array}$ & $\begin{array}{l}\text { Dark blue in } \\
\text { letters }\end{array}$ & \\
\hline 147 & Alexandria & $\begin{array}{l}\text { Athens, National } \\
\text { Museum M } 1456\end{array}$ & $\begin{array}{l}\text { Dark blue in } \\
\text { letters }\end{array}$ & \\
\hline 149 & Alexandria & $\begin{array}{l}\text { Alexandria Museum } \\
\text { T } 59\end{array}$ & $\begin{array}{l}\text { Greenish in } \\
\text { altar } \\
\text { garlands, } \\
\text { blue in } \\
\text { letters of } \\
\text { inscription }\end{array}$ & \\
\hline 153 & $\begin{array}{l}\text { Alexandria, } \\
\text { Hadra }\end{array}$ & $\begin{array}{l}\text { Alexandria Museum } \\
5690\end{array}$ & $\begin{array}{l}\text { Dark in altar } \\
\text { garlands }\end{array}$ & \\
\hline 155 & $\begin{array}{l}\text { Alexandria, } \\
\text { Hadra }\end{array}$ & $\begin{array}{l}\text { Alexandria Museum } \\
5692\end{array}$ & $\begin{array}{l}\text { Dark blue in } \\
\text { altar } \\
\text { garlands }\end{array}$ & \\
\hline 156 & $\begin{array}{l}\text { Alexandria, } \\
\text { Hadra }\end{array}$ & $\begin{array}{l}\text { Alexandria Museum } \\
5693\end{array}$ & $\begin{array}{l}\text { Dark blue } \\
\text { on bit of } \\
\text { altar } \\
\text { garland }\end{array}$ & \\
\hline
\end{tabular}




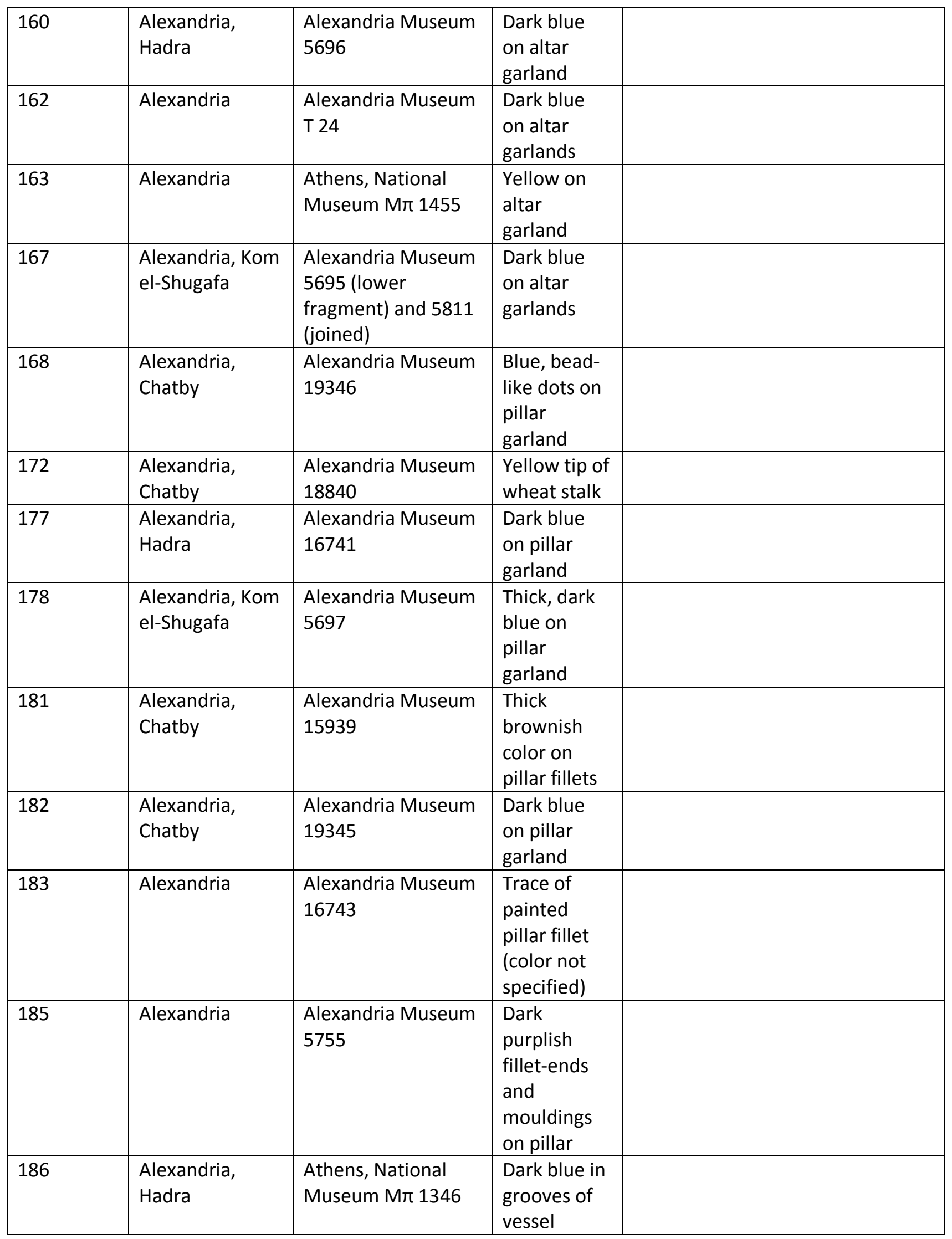




\begin{tabular}{|c|c|c|c|c|}
\hline & & & $\begin{array}{l}\text { handle, } \\
\text { brown on } \\
\text { fillets } \\
\text { underneath } \\
\text { handle }\end{array}$ & \\
\hline 193 & $\begin{array}{l}\text { Alexandria, Kom } \\
\text { el-Shugafa }\end{array}$ & $\begin{array}{l}\text { Alexandria Museum } \\
5817\end{array}$ & $\begin{array}{l}\text { Traces of } \\
\text { dark blue in } \\
\text { letters of } \\
\text { shoulder } \\
\text { inscription }\end{array}$ & \\
\hline 198 & $\begin{array}{l}\text { Alexandria, } \\
\text { Hadra }\end{array}$ & $\begin{array}{l}\text { Alexandria Museum } \\
19364\end{array}$ & $\begin{array}{l}\text { Dark in } \\
\text { letters of } \\
\text { shoulder } \\
\text { inscription }\end{array}$ & \\
\hline 209 & Alexandria & $\begin{array}{l}\text { Athens, L. Benaki } \\
\text { Collection } \Sigma \wedge M 182\end{array}$ & $\begin{array}{l}\text { Brownish } \\
\text { black on } \\
\text { forehead, } \\
\text { hair, beard, } \\
\text { brows, and } \\
\text { eyes of } \\
\text { Satyr, } \\
\text { yellow on } \\
\text { fruit }\end{array}$ & \\
\hline 214 & Unprovenanced & $\begin{array}{l}\text { London, } \\
\text { Chesterman } \\
\text { Collection }\end{array}$ & $\begin{array}{l}\text { Dark on } \\
\text { Satyr's hair }\end{array}$ & \\
\hline 215 & $\begin{array}{l}\text { Alexandria, } \\
\text { Hadra }\end{array}$ & $\begin{array}{l}\text { Alexandria Museum } \\
5528\end{array}$ & $\begin{array}{l}\text { Dark blue- } \\
\text { green on } \\
\text { Satyr's hair }\end{array}$ & \\
\hline 216 & Alexandria & $\begin{array}{l}\text { Alexandria Museum } \\
\text { T 53a }\end{array}$ & $\begin{array}{l}\text { Dark blue } \\
\text { on Satyr's } \\
\text { beard }\end{array}$ & \\
\hline 217 & Alexandria & $\begin{array}{l}\text { Alexandria Museum } \\
19312\end{array}$ & $\begin{array}{l}\text { Dark on } \\
\text { Satyr's } \\
\text { beard }\end{array}$ & \\
\hline 218 & $\begin{array}{l}\text { Alexandria, } \\
\text { Hadra }\end{array}$ & $\begin{array}{l}\text { Alexandria Museum } \\
5541\end{array}$ & $\begin{array}{l}\text { Dark blue } \\
\text { on Satyr's } \\
\text { hair and } \\
\text { beard }\end{array}$ & \\
\hline 219 & Alexandria & $\begin{array}{l}\text { Alexandria Museum } \\
19311\end{array}$ & $\begin{array}{l}\text { Purplish- } \\
\text { blue on } \\
\text { Satyr's hair } \\
\text { and beard }\end{array}$ & \\
\hline 223 & Unprovenanced & $\begin{array}{l}\text { London, British } \\
\text { Museum E34896 }\end{array}$ & $\begin{array}{l}\text { Dark blue } \\
\text { on Satyr's } \\
\text { hair, brows, } \\
\text { beard }\end{array}$ & $\begin{array}{l}\text { Note that the BM online } \\
\text { collections database refers to the } \\
\text { object as a head of Silenus: } \\
\text { http://www.britishmuseum.org/re }\end{array}$ \\
\hline
\end{tabular}




\begin{tabular}{|c|c|c|c|c|}
\hline & & & & $\begin{array}{l}\text { search/collection online/collectio } \\
\text { n object details.aspx?objectld=10 } \\
\text { 1821\&partld=1\&searchText }=3489 \\
\text { 6\&page }=1\end{array}$ \\
\hline 234 & Alexandria & $\begin{array}{l}\text { Alexandria Museum } \\
\text { T } 23\end{array}$ & $\begin{array}{l}\text { Dark green } \\
\text { on Satyr's } \\
\text { hair }\end{array}$ & \\
\hline 255 & Unprovenanced & $\begin{array}{l}\text { Oxford, Ashmolean } \\
\text { Museum 1960.725 }\end{array}$ & $\begin{array}{l}\text { Black on } \\
\text { forehead, } \\
\text { brows, } \\
\text { eyeballs, } \\
\text { hair, and } \\
\text { beard of } \\
\text { Silenus }\end{array}$ & \\
\hline 256 & Alexandria & $\begin{array}{l}\text { Athens, National } \\
\text { Museum M } \pi 1336\end{array}$ & $\begin{array}{l}\text { Dark blue } \\
\text { on hair and } \\
\text { beard of } \\
\text { Silenus }\end{array}$ & \\
\hline 258 & Alexandria & $\begin{array}{l}\text { Athens, National } \\
\text { Museum M } \pi 1451\end{array}$ & $\begin{array}{l}\text { Dark blue } \\
\text { on hair and } \\
\text { beard of } \\
\text { Silenus }\end{array}$ & \\
\hline 259 & Unprovenanced & $\begin{array}{l}\text { Athens, National } \\
\text { Museum M } 1454\end{array}$ & $\begin{array}{l}\text { Dark blue } \\
\text { on hair and } \\
\text { beard of } \\
\text { Silenus }\end{array}$ & \\
\hline
\end{tabular}


Table 2: Oinochoai and fragments of oinochoai featuring gilding as reported in the catalogue of Dorothy Burr Thompson, The Ptolemaic Oinochoai and Portraits in Faience (1973)

\begin{tabular}{|c|c|c|c|c|}
\hline $\begin{array}{l}\text { Thompson } \\
\text { cat. no. }\end{array}$ & Provenance & Museum no. & $\begin{array}{l}\text { Location of } \\
\text { gilding }\end{array}$ & Additional remarks \\
\hline 1 & $\begin{array}{l}\text { Said to be from } \\
\text { Canosa } \\
\text { (purchased in } \\
\text { 1873) }\end{array}$ & $\begin{array}{l}\text { London, British } \\
\text { Museum } \\
1873,0820.389\end{array}$ & $\begin{array}{l}\text { Satyr volutes, } \\
\text { Silenus } \\
\text { wreath, base; } \\
\text { BM online } \\
\text { database } \\
\text { also notes } \\
\text { gilding on, } \\
\text { queen's fillet } \\
\text { and armband } \\
\text { on her left } \\
\text { arm }\end{array}$ & $\begin{array}{l}\text { See also } \\
\text { http://www.britishmuseum.org/res } \\
\text { earch/collection online/collection } \\
\text { object details.aspx?assetld=96722 } \\
\text { 6\&objectld=460427\&partld=1 }\end{array}$ \\
\hline 2 & Unprovenanced & $\begin{array}{l}\text { Munich, } \\
\text { Antikensammlung } \\
8720\end{array}$ & $\begin{array}{l}\text { Neck of dress } \\
\text { and fillet that } \\
\text { extends from } \\
\text { rim of } \\
\text { cornucopia }\end{array}$ & \\
\hline 5 & Unprovenanced & $\begin{array}{l}\text { Baltimore, } \\
\text { Walters Art } \\
\text { Museum } 48.315\end{array}$ & $\begin{array}{l}\text { Per } \\
\text { Thompson: } \\
\text { "Gilding on } \\
\text { hair fillet, } \\
\text { horn fillet, } \\
\text { edge of } \\
\text { chiton, } \\
\text { bracelets." }\end{array}$ & $\begin{array}{l}\text { Per Hill (1954: } 45) \text { : "There is no } \\
\text { gilt present, but thick-set tiny } \\
\text { dots in the glaze occur at exactly } \\
\text { the places where, by analogy } \\
\text { with similar fragments, one } \\
\text { would expect gilding; in a band } \\
\text { across the upper arm, in two } \\
\text { streamers diverging from the } \\
\text { back of the head, and along the } \\
\text { chiton at the spectator's left." }\end{array}$ \\
\hline 6 & Unprovenanced & $\begin{array}{l}\text { New York, } \\
\text { Metropolitan } \\
\text { Museum of Art } \\
\text { 17.1914.2392 }\end{array}$ & $\begin{array}{l}\text { Two } \\
\text { bracelets on } \\
\text { upper arms, } \\
\text { upper edges } \\
\text { of chiton }\end{array}$ & $\begin{array}{l}\text { See also } \\
\text { http://www.metmuseum.org/Colle } \\
\text { ctions/search-the- } \\
\text { collections/130011005?rpp=20\&pg } \\
=1 \& \mathrm{ft}=17.194 .2392 \& \mathrm{pos}=1\end{array}$ \\
\hline 8 & $\begin{array}{l}\text { Alexandria, Kom } \\
\text { el-Shugafa }\end{array}$ & $\begin{array}{l}\text { Alexandria } \\
\text { Museum } 5815\end{array}$ & $\begin{array}{l}\text { Unclear; per } \\
\text { Thompson: } \\
\text { "Gilding } \\
\text { noted in } \\
\text { Museum } \\
\text { Catalogue" }\end{array}$ & \\
\hline 24 & Alexandria & $\begin{array}{l}\text { Alexandria } \\
\text { Museum } 15942\end{array}$ & $\begin{array}{l}\text { Tassel of } \\
\text { garment } \\
\text { overfold }\end{array}$ & \\
\hline 25 & $\begin{array}{l}\text { Probably } \\
\text { Alexandria }\end{array}$ & $\begin{array}{l}\text { New York, } \\
\text { Metropolitan } \\
\text { Museum of Art } \\
\text { 26.7.1016 }\end{array}$ & Earring & $\begin{array}{l}\text { See also } \\
\text { http://www.metmuseum.org/Colle } \\
\text { ctions/search-the- } \\
\text { collections/100009159?rpp=20\&pg }\end{array}$ \\
\hline
\end{tabular}




\begin{tabular}{|c|c|c|c|c|}
\hline & & & & $=1 \& \mathrm{ft}=26.7 .1016 \&$ pos $=1$ \\
\hline 26 & Memphis & $\begin{array}{l}\text { Cairo, Egyptian } \\
\text { Museum CG } \\
18026\end{array}$ & $\begin{array}{l}\text { Borders of } \\
\text { himation, } \\
\text { shoe, tip of } \\
\text { cornucopia }\end{array}$ & \\
\hline 28 & $\begin{array}{l}\text { Alexandria, } \\
\text { Chatby }\end{array}$ & $\begin{array}{l}\text { Alexandria } \\
\text { Museum } 15936\end{array}$ & $\begin{array}{l}\text { Neck, side of } \\
\text { left breast, } \\
\text { edge of } \\
\text { overfold }\end{array}$ & \\
\hline 29 & $\begin{array}{l}\text { Benghazi } \\
\text { (acquired 1859) }\end{array}$ & $\begin{array}{l}\text { Paris, } \\
\text { Bibliothèque } \\
\text { Nationale F } 9083\end{array}$ & $\begin{array}{l}\text { Per } \\
\text { Thompson: } \\
\text { "Gilding on } \\
\text { hem of } \\
\text { chiton. } \\
\text { Yellowish on } \\
\text { hair." }\end{array}$ & $\begin{array}{l}\text { Per Beulé }(1862,167-8) \text { : gold } \\
\text { remains on pillar, phiale, diadem, } \\
\text { and around queen's neck on border } \\
\text { of garment }\end{array}$ \\
\hline 30 & Alexandria & $\begin{array}{l}\text { Paris, Louvre AM } \\
1847\end{array}$ & Breasts & \\
\hline 39 & Alexandria & $\begin{array}{l}\text { Athens, National } \\
\text { Museum } \mathrm{M} \pi \\
\text { 1330; }\end{array}$ & $\begin{array}{l}\text { Border of } \\
\text { skirt }\end{array}$ & \\
\hline 44 & $\begin{array}{l}\text { Athens, Agora } \\
\text { Excavations } \\
\text { deposit M 21:1 } \\
\text { (late third to } \\
\text { early second c. } \\
\text { BCE) }\end{array}$ & $\begin{array}{l}\text { Athens, Agora } \\
\text { Museum P } 18692 \\
\text { (five fragments) }\end{array}$ & Stephane & \\
\hline 60 & Memphis & $\begin{array}{l}\text { Cairo, Egyptian } \\
\text { Museum CG } \\
18027\end{array}$ & $\begin{array}{l}\text { Top edge of } \\
\text { chiton at } \\
\text { bosom, } \\
\text { overfold and } \\
\text { cornucopia }\end{array}$ & $\begin{array}{l}\text { See also Fr. W. von Bissing, } \\
\text { Fayencegefässe (Catalogue general } \\
\text { du musée du Caire) (Vienna, 1902) } \\
103 . \\
\text { http://hdl.handle.net/2027/mdp.39 } \\
015011243949 \\
\end{array}$ \\
\hline 63 & $\begin{array}{l}\text { Athens } \\
\text { (acquired 1837) }\end{array}$ & $\begin{array}{l}\text { New York, } \\
\text { Metropolitan } \\
\text { Museum of Art } \\
\text { 17.1914.1697 }\end{array}$ & $\begin{array}{l}\text { Per } \\
\text { Thompson: } \\
\text { "Gilding } \\
\text { down center } \\
\text { of horn } \\
\text { shaft." } \\
\text { Gilding also } \\
\text { visible on } \\
\text { garment } \\
\text { edge along } \\
\text { queen's } \\
\text { proper left } \\
\text { breast in } \\
\text { MMA online }\end{array}$ & $\begin{array}{l}\text { See also } \\
\text { http://www.metmuseum.org/Colle } \\
\text { ctions/search-the- } \\
\text { collections/130010663?rpp=20\&pg } \\
=1 \& \mathrm{ft}=17.194 .1697+\& \mathrm{pos}=1\end{array}$ \\
\hline
\end{tabular}




\begin{tabular}{|c|c|c|c|c|}
\hline & & & database & \\
\hline 64 & $\begin{array}{l}\text { Alexandria, } \\
\text { Hadra }\end{array}$ & $\begin{array}{l}\text { Alexandria } \\
\text { Museum } 19294\end{array}$ & Bosom & \\
\hline 66 & Unprovenanced & $\begin{array}{l}\text { Alexandria } \\
\text { Museum } 16171\end{array}$ & $\begin{array}{l}\text { Throat of } \\
\text { cornucopia }\end{array}$ & \\
\hline 73 bis. & Egypt & $\begin{array}{l}\text { Bonn, } \\
\text { Akademisches } \\
\text { Kunstmuseum } \\
1230\end{array}$ & $\begin{array}{l}\text { Roll of } \\
\text { himation and } \\
\text { along its } \\
\text { edges }\end{array}$ & \\
\hline 74 & $\begin{array}{l}\text { Alexandria, } \\
\text { Chatby }\end{array}$ & $\begin{array}{l}\text { Alexandria } \\
\text { Museum } 19344\end{array}$ & Stephane & \\
\hline 75 & Xanthos, Lycia & $\begin{array}{l}\text { Antalya Museum } \\
571\end{array}$ & $\begin{array}{l}\text { Rim of } \\
\text { cornucopia, } \\
\text { base of } \\
\text { vessel, phiale }\end{array}$ & $\begin{array}{l}\text { Per Demargne }(1958,54) \text { : "on a des } \\
\text { traces de dorure sur le rebord du } \\
\text { bec, au ressaut du pied et sur la } \\
\text { patère tenue par la reine." }\end{array}$ \\
\hline 87 & $\begin{array}{l}\text { Said to be from } \\
\text { Canosa } \\
\text { (Acquired in } \\
\text { Italy, } \\
\text { bequeathed to } \\
\text { museum in } \\
1856 \text { ) }\end{array}$ & $\begin{array}{l}\text { London, British } \\
\text { Museum GR } \\
\text { 1856.12-26.192 } \\
\text { (Vases K 76) }\end{array}$ & $\begin{array}{l}\text { Moulding of } \\
\text { pillar base }\end{array}$ & \\
\hline 106 & $\begin{array}{l}\text { Alexandria, } \\
\text { Chatby }\end{array}$ & $\begin{array}{l}\text { Alexandria } \\
\text { Museum } 22582\end{array}$ & $\begin{array}{l}\text { Per } \\
\text { Thompson: } \\
\text { "Traces of } \\
\text { gilding in } \\
\text { many } \\
\text { places." }\end{array}$ & \\
\hline 109 & $\begin{array}{l}\text { Said to be from } \\
\text { Lower Egypt } \\
\text { (purchased } \\
\text { between } 1910 \\
\text { and 1915) }\end{array}$ & $\begin{array}{l}\text { Baltimore, } \\
\text { Walters Art } \\
\text { Museum } 48.309\end{array}$ & $\begin{array}{l}\text { Cornucopia, } \\
\text { edge of } \\
\text { himation, } \\
\text { and fillet }\end{array}$ & \\
\hline 124 & $\begin{array}{l}\text { Alexandria, } \\
\text { Chatby }\end{array}$ & $\begin{array}{l}\text { Alexandria } \\
\text { Museum } 18242\end{array}$ & $\begin{array}{l}\text { Per } \\
\text { Thompson: } \\
\text { "Gilding on } \\
\text { drapery at } \\
\text { left side." }\end{array}$ & \\
\hline 128 & $\begin{array}{l}\text { Alexandria, } \\
\text { Chatby }\end{array}$ & $\begin{array}{l}\text { Alexandria } \\
\text { Museum } 16258\end{array}$ & $\begin{array}{l}\text { Fillet and } \\
\text { earring }\end{array}$ & \\
\hline 132 & Unprovenanced & $\begin{array}{l}\text { Alexandria } \\
\text { Museum } 23948 \\
\end{array}$ & Fillet & \\
\hline 178 & $\begin{array}{l}\text { Alexandria, Kom } \\
\text { el-Shugafa }\end{array}$ & $\begin{array}{l}\text { Alexandria } \\
\text { Museum } 5697\end{array}$ & $\begin{array}{l}\text { Ends of } \\
\text { garland } \\
\text { around pillar }\end{array}$ & \\
\hline 187 & Alexandria & $\begin{array}{l}\text { Athens, National } \\
\text { Museum M } 1344\end{array}$ & $\begin{array}{l}\text { Lip of vessel } \\
\text { mouth }\end{array}$ & \\
\hline
\end{tabular}




\begin{tabular}{|l|l|l|l|l|}
\hline 188 & Alexandria & $\begin{array}{l}\text { Alexandria } \\
\text { Museum T 72 }\end{array}$ & Inside of lip & \\
\hline 203 & $\begin{array}{l}\text { Alexandria, } \\
\text { Chatby }\end{array}$ & $\begin{array}{l}\text { Alexandria } \\
\text { Museum 18257 }\end{array}$ & $\begin{array}{l}\text { Outer and } \\
\text { central ridges } \\
\text { of handle } \\
\text { fragment }\end{array}$ & \\
\hline 205 & $\begin{array}{l}\text { Alexandria, } \\
\text { Hadra }\end{array}$ & $\begin{array}{l}\text { Alexandria } \\
\text { Museum 16342 }\end{array}$ & $\begin{array}{l}\text { Flanges of } \\
\text { handle } \\
\text { fragment }\end{array}$ & \\
\hline 218 & $\begin{array}{l}\text { Alexandria, } \\
\text { Hadra }\end{array}$ & $\begin{array}{l}\text { Alexandria } \\
\text { Museum 5541 }\end{array}$ & $\begin{array}{l}\text { Volutes of } \\
\text { Satyr mask }\end{array}$ & \\
\hline 228 & $\begin{array}{l}\text { Alexandria, } \\
\text { Hadra }\end{array}$ & $\begin{array}{l}\text { Alexandria } \\
\text { Museum 5736 }\end{array}$ & $\begin{array}{l}\text { Forehead of } \\
\text { Satyr }\end{array}$ & \\
\hline
\end{tabular}

